\title{
Belleza femenina, estética e ideología. Las reinas del trabajo durante el peronismo
}

\author{
Mirta Zaida Lobato, María Damilakou \\ y Lizel Tornay ${ }^{1}$ \\ Universidad de Buenos Aires
}

\begin{abstract}
El objetivo de este trabajo es analizar los vínculos entre rituales, belleza femenina y acción política en Argentina bajo el peronismo. El estudio abarca dos períodos históricos bien definidos: los del primer peronismo entre 1948-1955 y los dos años de gobierno que antecedieron a la muerte de Juan Domingo Perón entre 1974-1975. La elección de las reinas del trabajo formaba parte de un culto de masas articulado por la imagen y de una liturgia donde se mezclaban ritos y símbolos diversos. Era un espectáculo político que se imbricaba con una formulación de "belleza femenina" y con una estética de ostentosa monumentalidad. En ese espectáculo las fotografías tuvieron un papel importante que es examinado en el análisis que se realiza.
\end{abstract}

PALABRAS ClAVE: Género, belleza, peronismo, trabajadores, rituales, mujeres obreras, fotografía.

The goal of this article is to analyze the links among rituals, the concept of feminine beauty and political action in Argentina under the age of peronismo. In this context, this analysis focuses on two clearly defined historical periods: the first one takes place between 1948-1955, and the second one covers the two years preceding Perón's death (1974-1975).

The election of the "Working Queens" was part of a masses cult stressed by images related to liturgy in which various rites and symbols were mixed. It was a political spectacle which overlapped a formulation of "feminine beauty" with an aesthetic of ostentatious monumentalism. In addition, the photographs played an important role within this spectacle and they are being examined in this analysis as well.

KEYwORDS: Gender, beauty, peronismo, workers, rituals, workers women, photography.

El 5 de mayo de 1949 el diario Democracia publicaba la propaganda de "Manuelita", el jabón de tocador de la empresa Jabón Federal. Ruth Sesma Romero era la cara triunfante de la publicidad (fig. 1). ${ }^{2}$ La joven,

1 Instituto Interdisciplinario de Estudios de Género (IIEGE), Archivo Palabras e Imágenes de Mujeres (APIM), Facultad de Filosofía y Letras, Universidad de Buenos Aires.

2 Aunque no sea el objetivo de este trabajo se puede señalar que la publicidad de jabones tiene ciertos rasgos peculiares. En ese universo publicitario la fotografía constituye su culminación. Además la imagen es propia del cine y se relaciona con el "consejo de las estrellas". El cuerpo del jabón es fundamentalmente el rostro y aparece como garante de lo natural frente a los artificios de los productos cosméticos como por ejemplo los polvos. Esta propaganda se vincula además con la historia pues alude a la época de Rosas en la figura de su hija Manuelita. Para un análisis de la publicidad gráfica véase Traversa, Oscar: Cuerpo de papel. Figuraciones del cuerpo en la prensa 1918-1940, Gedisa, Buenos Aires, 1997. 
nacida en la provincia de Tucumán había sido coronada Reina de la Zafra unos meses antes - el cultivo de caña de azúcar y la producción azucarera era la principal actividad económica de esa provincia desde fines del siglo XIX - y Reina Nacional del Trabajo 1949 en el multitudinario acto realizado en la Plaza de Mayo. María Eva Duarte de Perón la coronó y le hizo entrega de los atributos de realeza.

La elección de Ruth Sesma Romero no fue la primera. En 1948 el periódico El Laborista organizó un concurso para elegir la Reina del Trabajo, que se transformaría en parte del ritual de los actos oficiales entre 1948 y 1955. La "fiesta" del 1 de mayo de ese año comenzó el 30 de abril con una concentración de alumnos de escuelas primarias y secundarias frente al Monumento al Trabajo. El Programa oficial incluía la participación de la orquesta y ballet del teatro Colón, el desfile de carrozas alusivas y la elección de la reina. Las carrozas recorrieron diferentes calles del centro de la ciudad y convocaron a miles de personas.

Con el derrocamiento del gobierno peronista desapareció el ritual del 1 de mayo y la elección de las reinas tal como había sido delineado por el régimen. Recién en 1974 se realizaría una nueva elección pero sin la ostentación ni la monumentalidad del pasado. La tercera esposa del caudillo político, Isabel Martínez de Perón, coronó a la reina de ese año y a la de 1975, convertida ya en Presidente de la Nación a raíz de la muerte de su esposo.

Las "reinas" del primer peronismo han sido mencionadas en diversos trabajos como parte de la propaganda del régimen peronista, ${ }^{3}$ sin embargo no solamente puede ser explicado este ritual como un elemento más de esa propaganda para obtener consenso político o como la exteriorización de una ruptura con el pasado. Sin duda, el ritual del 1 de mayo servía para exaltar la nación de los trabajadores, pero la elección de una reina del trabajo implica también una exhibición pública del cuerpo de una mujer que se aleja de las imágenes más frecuentemente conocidas sobre las mujeres que trabajan.

Como señala Whitney Chadwick, es larga la historia en la que la representación del cuerpo femenino se ha organizado en función del placer visual masculino, pero en esas representaciones el cuerpo femenino

3 Plotkin, Mariano: Mañana es San Perón, Ariel, Buenos Aires, 1994, y Ballent, Anahí: Las huellas de la política. Arquitectura, vivienda y ciudad en las propuestas del peronismo. Buenos Aires (1946-1955), Tesis de doctorado, Facultad de Filosofía y Letras, UBA, Buenos Aires, Marzo de 1997, mimeo. 
adquiere las formas que le dicta la voluntad erótica del artista. ${ }^{4}$ En nuestro caso las reinas parecen integrarse al "mito de la belleza" definido como una cualidad natural, universal e inmutable, relacionado con la existencia de una mujer ideal. La mujer ideal se separa en muchos aspectos de las representaciones que desde la literatura se realizaron sobre las mujeres que trabajan (cuerpos deformes, la belleza deslucida), y eran exhibidas en una fiesta que brillaba por su magnificencia, por las banderas, por las carrozas, por las flores y por el espectáculo.

La elección de las reinas del trabajo formaba parte de un culto de masas que no se articulaba por medio de la palabra sino por la imagen y en una liturgia donde se mezclaban ritos y símbolos diversos. Era un espectáculo político que se imbricaba con una formulación de "belleza femenina" y con una estética de ostentosa monumentalidad.

¿Cuál fue la relación entre rituales, belleza femenina y acción política durante 1948 y 1955? ¿Cómo analizar el conjunto de imágenes producidas cada año y diseminadas por la prensa? ¿Qué nos dicen sobre las relaciones de género en el primer peronismo? Estos interrogantes son los que trataremos de responder a lo largo de este trabajo, que se basa en el análisis de fotografías conservadas en el Archivo General de la Nación (AGN) y las publicadas en los diarios de la época y en la prensa peronista.

Se trata de fotografías testimoniales. La foto testimonial es la foto de reportaje tomada en vivo (no en un estudio) y su fundamento reside en captar el instante del evento, es siempre instantánea en oposición a la foto posada. La fotografía testimonial constituye la captación del acontecimiento del que se habla en el texto que la acompaña y constituye el paradigma de la imagen fotográfica en la prensa de información. ${ }^{5}$ En el ámbito internacional, la revista Life descolló por el uso de este tipo de fotografía, pero en nuestro país fue utilizada profusamente al comenzar el siglo XX por la revista Caras y Caretas.

En las fotografías el disparo del fotógrafo interrumpe el acontecimiento, lo inmoviliza y con eso obliga al espectador a tomar una posición en cuanto a su papel. Si esas interrupciones se multiplican, se multiplican también las posiciones. Se podría decir que delante de esas interrupciones el espectador de fotografías se forma una imagen de sí y de los aconteci-

4 Chadwick, Whitney: Mujer arte y sociedad, Ediciones Destino, Barcelona, 1999.

5 Verón, Eliseo: "De la imagen semiológica a las discursividades. El tiempo de una fotografía", en Veyrat-Masson, Isabel y Dayan, Daniel (comps.): Espacios públicos en imágenes, Gedisa, Barcelona, 1997. 
mientos. ${ }^{6}$ La interrupción tiene una función organizadora de significados que produce su impacto sobre los espectadores. ¿De qué manera esas representaciones fotográficas de mujeres contribuyeron a crear sentidos, a construir identidades (entendida como posiciones) entre quienes las miraban?

Dice John Berger que la cámara fotográfica nos libra del peso de la memoria, pero que la fotografía pública, al ser separada de su contexto, se convierte en un objeto muerto que, por eso, puede ser utilizada de manera arbitraria. ${ }^{7}$ Sin embargo, las fotografías plantean siempre una tensión permanente entre diversos elementos: universales, particulares, instantáneos. Es precisamente por eso que se necesita también de un "lector privilegiado", que tiene conocimiento del contexto y acceso a otra información, que desbroce los elementos universales de lo fragmentario. ${ }^{8}$ ¿Cómo puede recuperarse la continuidad de los significados de estas fotografías olvidadas en un cajón del Archivo Nacional?

Para responder a los interrogantes que nos estamos formulando analizaremos brevemente los rituales y símbolos del peronismo durante el 1 de mayo, los escenarios y la escenografía, así como el proceso de elección de las reinas del trabajo y las imágenes que emergen de las fotografías. Sólo parcialmente y a través de la prensa nos acercaremos a sus voces.

\section{EI 1 de mayo: la fiesta de los trabajadores}

El 1 de mayo fue instituido como rito obrero internacional en 1890. $\mathrm{Su}$ establecimiento fue el resultado de un acto político deliberado y la manifestación de crear una clase - la clase obrera - a través de la pedagogía de la fiesta. En parte fue una creación desde arriba, de las corrientes más organizadas de los trabajadores en términos políticos. Con la fiesta se instauró una tradición con símbolos, eslóganes y recursos, que se sumaron a la preocupación de hacer visible a la multitud como señal ostensible del consenso al que habían llegado los trabajadores.

En Buenos Aires se formó también un comité para llevar a cabo los acuerdos que se habían tomado en el Congreso de París de 1889. El Comité Internacional Obrero convocó a un mitin para el 1 de mayo y propuso crear

6 Feldman-Bianco, Bela y Moreira Leite, Miriam: Desafios da imagen. Fotografía, iconografía e vídeo nas ciencias sociales, Papirus, Campinas, Sâo Paulo, 1998.

7 Berger, John: Mirar, Ediciones de la flor, Buenos Aires, 1998 (Primera edición en inglés 1980), pág. 77.

8 James, Daniel and Lobato, Mirta Zaida: "Family Photos. Oral Narratives and Identity Formation: the Ukrainians of Berisso", en HARR (en prensa). 


\section{LAS REINAS DEL TRABAJO DURANTE EL PERONISMO}

Fig. 1.-1949, Propaganda de Jabón Manuelita de la compañía Jabón Federal, Democracia, 5 de mayo de 1949.
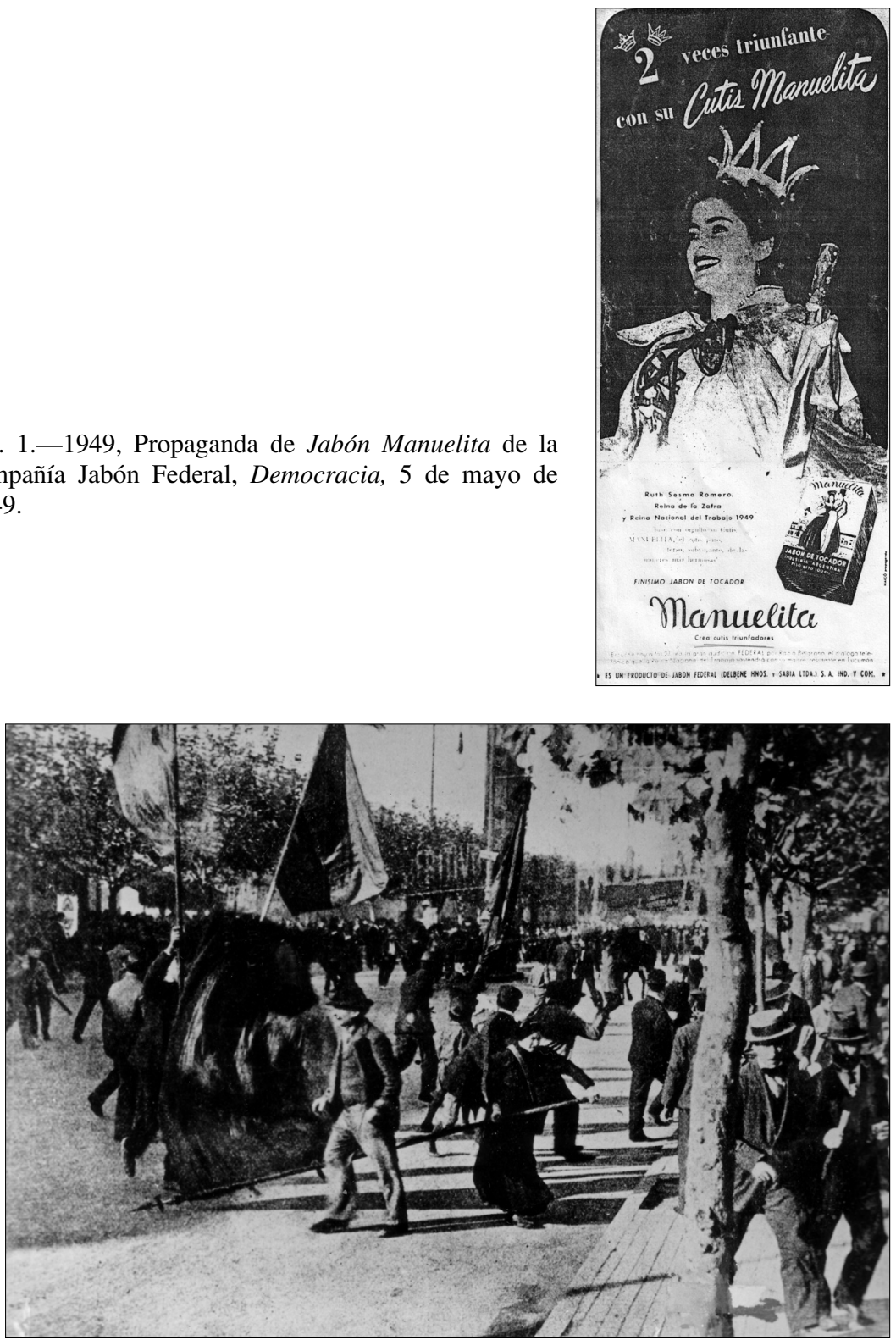

Fig. 2.-Manifestación del 1 de mayo de 1909. Entre los manifestantes destaca una mujer con una bandera que escapa de la represión policial, Archivo General de la Nación (AGN). 


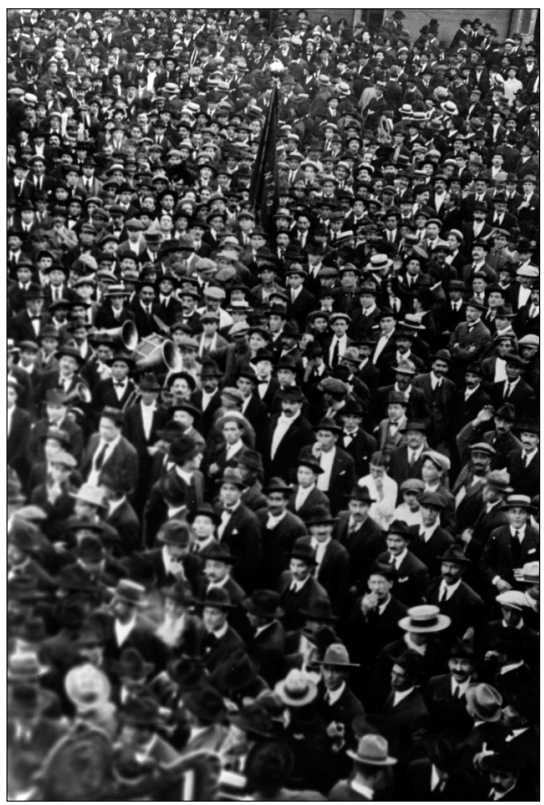

Fig. 3.-Manifestación socialista del 1 de mayo de 1924, AGN.

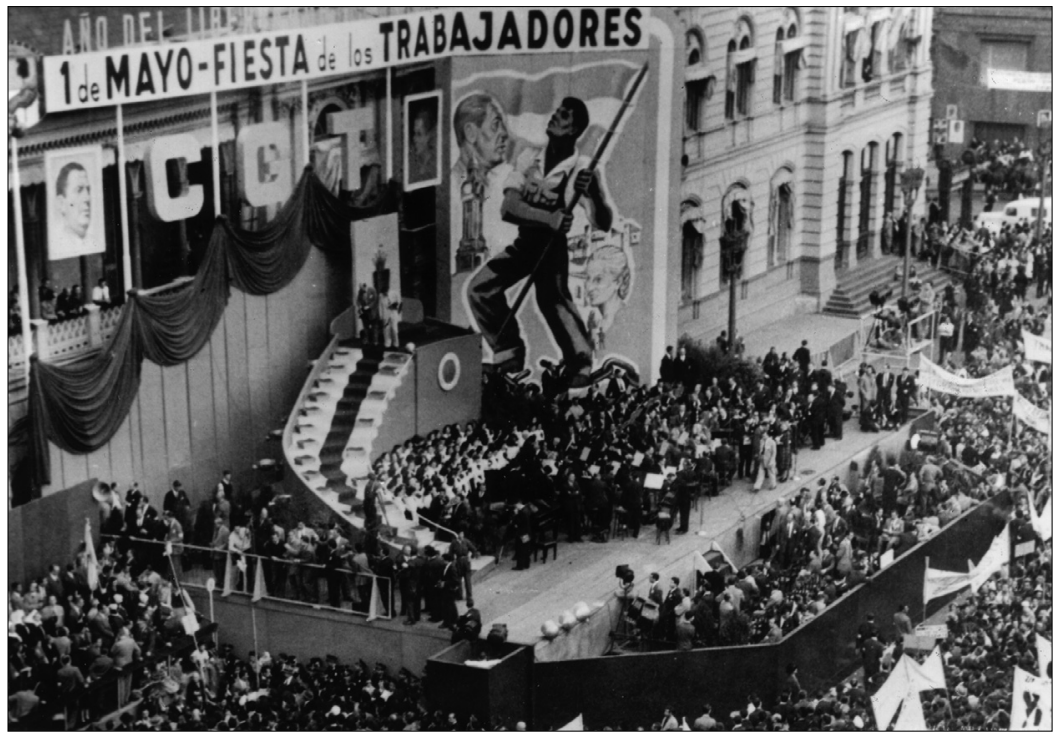

Fig. 4.-1 de mayo de 1950, AGN. 
una Federación de Obreros en la República, un periódico para la defensa de la clase obrera, y mandar un petitorio al Congreso para crear leyes protectoras de los trabajadores. ${ }^{9}$

El rito obrero del 1 de mayo estuvo en el centro de las controversias de las corrientes ideológicas vinculadas al movimiento obrero. Al principio socialistas y anarquistas compartieron el espacio común de inventar tradiciones obreras, de producir símbolos y construir rituales, a los que se sumaron sindicalistas y comunistas. Símbolos y ritos adquirieron connotaciones diferentes para socialistas, anarquistas y comunistas.

Las manifestaciones del primero de mayo podían ser ordenadas, respetuosas del orden público, acompañadas de himnos revolucionarios o tumultuosas y hasta violentas cuando se producía la intervención de las fuerzas policiales (Fig. 2 y 3). ${ }^{10}$ Entre 1890 y 1946, fecha en la que se festejó por primera vez el 1 de mayo bajo el gobierno de Juan Domingo Perón, se realizaron cientos de actos en la ciudad de Buenos Aires y otras del interior del país. Sólo unos pocos de ellos han pasado a la historia por sus niveles de violencia.

Según Juan Suriano, el anarquismo demostró siempre un profundo rechazo de las concepciones reformista y festiva que tenía la jornada para el socialismo. Para los anarquistas el 1 de mayo no podía tener un carácter festivo, porque desviaba la verdadera significación de la protesta. La consideraba una jornada de luto y dolor por los centenares de trabajadores reprimidos, muertos, heridos y detenidos en las movilizaciones reivindicativas y por la explotación capitalista. Para los anarquistas ese día debía expresarse la tristeza, la desesperación y el odio engendrados por los sufrimientos que imponían los patronos y amos. ${ }^{11}$

Frente a estas dos tradiciones, el peronismo produjo tanto una ruptura como un cambio de sentido de los rituales obreros. ${ }^{12}$ La jornada del 1 de mayo se convirtió en un combate por el espacio simbólico y fue cambiando hasta adquirir el tono apoteósico que se observa en la fotografía de 1950 (fig. 4).

9 Lobato, Mirta Zaida (dir.): El progreso, la modernización y sus límites, 1880-1916, Nueva Historia Argentina, Sudamericana, Buenos Aires, 2000.

10 Viguera, Aníbal: "El primero de mayo en Buenos Aires, 1890-1950: revolución y usos de una tradición", en Boletín N. 3 del Instituto de Historia Argentina y Americana Dr. Emilio Ravignani, 3. ${ }^{a}$ Serie, 1er semestre de 1991, y Suriano, Juan: Anarquistas. Cultura y política libertaria en Buenos Aires, 1890-1910, Manantial, Buenos Aires, 2001.

11 Suriano: Anarquistas..., en particular el capítulo VIII.

12 El análisis de los rituales peronistas ha sido realizado por Plotkin,: Mañana... 
El 1 de mayo de 1946 fue el primero que presidió Perón. El acto principal fue convocado por la CGT, los sindicatos autónomos y contó con el apoyo del Partido Laborista, quien se había convertido en el partido que dio base de sustento a la movilización política, que terminó con el triunfo electoral de febrero de 1946. La columna de manifestantes fue encabezada por Juan Domingo Perón, María Eva Duarte, el coronel Mercante y el Secretario de Trabajo y Previsión, Russo. Por primera vez, en 55 años de historia de los 1 de mayo, las autoridades nacionales encabezaban la marcha junto a los trabajadores. Por primera vez también, Perón asoció la fecha con el emergente movimiento peronista.

El 1 de mayo de 1946 se inició un proceso de apropiación de los símbolos y significados asociados al día de los trabajadores y a las ideologías que habían pugnado por orientarlos. En principio, fue asociado a la victoria obtenida por el pueblo el 17 de octubre de 1945, cuando los trabajadores se movilizaron para liberar a Perón de la cárcel en la que había sido confinado por sus compañeros de armas. La CGT enfatizó que se trataba de un "día de sana alegría y verdadero descanso del músculo".

El 1 de mayo fue un día de fiesta porque, como resultado del triunfo del peronismo, los trabajadores podían encarnar el sentimiento nacional. Además la presencia de Perón implicaba una clara ruptura con el pasado, donde los gobiernos oligárquicos reprimían a los trabajadores, lo que provocaba violentos enfrentamientos.

Este ayer enunciado con palabras se convirtió en imágenes en 1949, cuando se publicó el folleto "1 de Mayo ayer y hoy". El ayer estaba marcado por los "excesos, torpes y abusivos" que alimentaban el "odio que se convertía en sangre humilde cada 1 de mayo". El ayer estaba marcado por "crespones, cuando los capitalistas contribuían a la división de las masas populares e inclusive 'fabricaban' víctimas, con sádico regocijo de los agitadores importados, y los trabajadores no encontraban respuesta a sus justas demandas en los gobiernos ni en los parlamentos". En contraposición, la Argentina de hoy era la de la "patria redimida" y por eso "el 1 de mayo no es ya la fecha propicia al dolor y la desgracia, sino a la alegría. La Fiesta del Trabajo, realizada jubilosamente por quienes trabajan en la edificación de la Patria".13

13 Folleto 1 de mayo ayer y hoy, s/f. La prensa también enfatizaba esa imagen de ruptura. Por ejemplo en el diario Democracia se expresaba que: "La celebración del Día de los Trabajadores, que no hace muchos años se limitaba a rencorosas expresiones de rebeldía y a tumultuosas manifestaciones callejeras presididas por la bandera roja, es ahora un acontecimiento que congrega al país entero en un mismo impulso de júbilo y de gratitud" (2 de mayo de 1949). 
La idea de John Berger sobre el uso arbitrario que se puede hacer de la fotografía pública cobra cuerpo en el folleto. La mayoría de las fotos corresponden a las tomadas por los reporteros de Caras y Caretas en 1909. La protesta anarquista del 1 de mayo de 1909 había sido duramente reprimida por la policía y, durante una semana, se sucedieron las manifestaciones y los choques violentos entre trabajadores y agentes del orden en las calles de la ciudad de Buenos Aires.

Una foto muestra a un grupo de personas llevando banderas. Bajo el título "banderas rojas" el epígrafe de la fotografía dice que "en 1909 el 1 de mayo fue sinónimo de anarquía y de muerte bajo el signo de las banderas rojas" (Fig. 2). En la misma página, en su parte inferior, incorporan otra fotografía donde se puede observar a una persona muerta rodeada por otros cuatro personajes. En el epígrafe se denuncia que las balas eran utilizadas por la oligarquía "para restarle fuerza a las manifestaciones de los trabajadores". Las fotos de muertos y heridos se suceden en las páginas siguientes.

El hoy en el folleto comenzaba con la transcripción de los derechos del trabajador y de la ancianidad, una fotografía de página entera de Perón hablando a la multitud (la voz de Perón es la portadora de la verdad, que es la verdad del pueblo) y otra de doble página de la multitud en la plaza de Mayo bajo el título "El júbilo de un millón de trabajadores dueños de sus derechos y conquistas". En las páginas siguientes fotos de las reinas del trabajo.

El 1 de mayo de 1947 fue tomado por la prensa peronista, La Época, El Líder, El Laborista, en su carácter de fiesta nacional. También comenzó a enfatizarse que dicha jornada tendría otro sentido, pues serviría como muestra de homenaje y gratitud hacia Perón, quien había llevado felicidad al pueblo.

Según Mariano Plotkin, Oscar Ivanissevich fue nombrado Secretario de Educación y desde ese cargo influyó en la conformación de la simbología política del peronismo. Como miembro del Comité organizador de las celebraciones del 1 de mayo y del 17 de octubre colaboró activamente en la organización de la liturgia peronista. ${ }^{14}$

En 1947, desde las páginas de El Laborista se impulsó la elección de la reina del trabajo. Este diario había sido creado a fines de 1945, bajo la dirección de Angel Gabriel Borlenghi, y representaba los puntos de vista

14 Plotkin: Mañana... 
del partido y de los sindicatos; pero cuando se produjo la disolución del Partido Laborista, en 1946, el diario fue tomado por un grupo afín al coronel Mercante. ${ }^{15}$

La elección oficial de la primera reina del trabajo se produjo el 1 de mayo de 1948 y, a partir de entonces, se repitió todos los años hasta 1955. Se incorporaba así un ritual dentro de otro protagonizado por la belleza de la mujer.

\section{El escenario y el espectáculo}

Las fotografías públicas capturan una pose que puede constituirse en un discurso sobre aquello que se quiere sostener socialmente. Anahí Ballent opina que las políticas del peronismo anudaban la propaganda política con las masas y el teatro como formas particulares de ocupación del espacio público. En las concentraciones masivas del peronismo, aunque el elemento convocante era la política, también se estimulaba la difusión cultural, el espectáculo y el esparcimiento popular. ${ }^{16}$

Política, cultura, espectáculo y esparcimiento se encontraban reunidos en la fiesta del 1 de mayo. La política se materializaba en el cambio de sentido del rito obrero que ahora formaba parte de la identidad del peronismo. El espectáculo adquiría fuerza en el desfile de carrozas y en la escenografía que se montaba frente a la casa de gobierno. El esparcimiento se materializaba con la fiesta que convocaba a los trabajadores y su familia. La cultura cobraba sentido con las representaciones musicales, los bailes y la presencia de los artistas en el palco oficial. En los actos del 1 de mayo se difundía música clásica y folklore, podía actuar la orquesta sinfónica nacional o el ballet del teatro Colón.

Al convertir el 1 de mayo en espectáculo se asignaban nuevos sentidos y usos a los espacios existentes. Por ejemplo, el escenario que se montó frente a la casa de gobierno en 1950 colocaba a la CGT a la par de Perón y Evita en cuanto a los convocantes, pero el afiche muestra a un trabajador que dirige su cuerpo y su mirada hacia la cara de Juan Domingo Perón en una posición que denota cierta subordinación. La escalera donde ocuparían su sitio las reinas del trabajo provinciales se eleva, a su vez, hacia las fotos

15 Plotkin: Mañana..., pág. 326, y Sirven, Pablo: Perón y los medios de comunicación (19431959), CEAL, Buenos Aires, 1984.

16 Ballent: Las huellas... 
de los "conductores" del pueblo y hacia las letras de la máxima organización de los trabajadores (Figs. 4 y 18).

La Casa de Gobierno y la Plaza de Mayo se convirtieron en los espacios públicos privilegiados para la realización de los actos peronistas. Sin embargo, para los festejos del 1 de mayo se incorporó un nuevo ámbito: el edificio de la CGT. Además la organización del desfile de la reina y de su séquito se realizaba por las principales avenidas de la ciudad (Avenida Corrientes, 9 de Julio, Callao y de Mayo) y podía detenerse en el Congreso Nacional.

El escenario era amplio, aunque el centro del mismo estuviera ubicado en la Plaza de Mayo. El espectáculo también se amplió. Por ejemplo, el 1 de mayo de 1948 el acto se abrió con la ejecución del Himno Nacional y la marcha Canto al trabajo por la banda del Colegio Militar. Ese año y los sucesivos los manifestantes cantaban la marcha Los muchachos peronistas. ${ }^{17}$ En 1952 se desarrolló un programa artístico organizado por la CGT, que contó con destacadas figuras del teatro, del cine y la radiotelefonía. Desfilaron ante el público la primera actriz Fanny Navarro, quien interpretó el poema de Jorge Mar Capitana de mi pueblo. ${ }^{18}$ Hugo del Carril, Luis Sandrini, Los hermanos Abalos, Pinocho, Agustín Irusta, Iris Marga,

17 Los muchachos peronistas / Los muchachos peronistas / Todos unidos triunfaremos / Y como siempre daremos / Un grito de corazón: / ¡Viva Perón! ¡Viva Perón! / Por ese gran argentino / Que se supo conquistar / A la gran masa del pueblo / Combatiendo al capital. / ¡Perón, Perón, qué grande sos! / ¡Mi general, cuánto valés! / ¡Perón, Perón, gran conductor, / sos el primer trabajador! / Con los principios sociales / Que Perón ha establecido / El pueblo entero está unido / Y grita de corazón / ¡Viva Perón! ¡Viva Perón! Por ese gran argentino / Que trabaja sin cesar, para que reine en el pueblo / El amor y la igualdad. / ¡Perón, Perón, qué grande sos! / ¡Mi general, cuánto valés! / ¡Perón, Perón, gran conductor, / sos el primer trabajador! / Imitemos el ejemplo / De este varón argentino / Y siguiendo su camino / Gritemos de corazón: / ¡Viva Perón! ¡Viva Perón! / Porque la Argentina grande / Con que San Martín soñó, / es la realidad efectiva / Que debemos a Perón. / ¡Perón, Perón, qué grande sos! / ¡Mi general, cuánto valés! / ¡Perón, Perón, gran conductor, / sos el primer trabajador! Cancionero de Juan Perón y Eva Perón, Realizado por el equipo del GE de BA bajo la dirección de Julio Darío Alessandro, Grupo Editor de Buenos Aires, Buenos Aires, 1966, págs. 309 y 310.

18 Capitana de mi pueblo / Tenía sed en los ojos / Y en la carne y en los nervios... / ¡Una sed amarga y dura! / Como una rosa, en el pecho, / Le dolía la esperanza / Y el amor... todo mi pueblo / Tenía sed en los ojos / Y en la carne y en los nervios... / Quería verla otra vez / Como en sus mejores tiempos: / Linda, fanática y fuerte / Gritando su amor de fuego / Con sus palabras de luz, / Afiladas como acero / De coraje y de bravura, / De dolor y de despecho / ¡linda, fanática y fuerte!, / Capitana de mi pueblo! / Cuando llegó, se nublaron / Los ojos limpios del pueblo. / El sol salió para verla / Dorándole sus cabellos. / La Patria que estaba allí / La bendecía en silencio. / Y en cada descamisado / Dios le mandaba sus besos. / Y lloraron su dolor / Y su amor y sus anhelos / Los hombres y las mujeres, / Los niños y los abuelos... / ¡Cada lágrima flameaba / como una bandera al viento / sobre el mástil de un amor / que casi tocaba el cielo! / ¡Nunca un pueblo de la tierra / lloró así... como mi pueblo! / Tampoco nadie lo amó / Como ella... con tanto fuego / Como ella... linda y fanática / Capitana de mi pueblo! / Las lágrimas y el amor / Son oraciones y versos: / Dos maneras de rezar / Que siempre llegan al cielo... / Por eso, Señor, 
Edmundo Rivero, Carlos Montbrun Ocampo y por último la orquesta típica de Julio de Caro. ${ }^{19}$

Las canciones expresaban claramente su adhesión a Perón y Evita. Capitana de mi pueblo retomaba las representaciones de Eva Perón como comprometida con los humildes, como una mujer apasionada, fuerte, fanática y bella, y la Marcha Peronista enfatizaba la condición de líder indiscutido de Perón. Canto al trabajo ${ }^{20}$ en cambio, escrita por Oscar Ivanissevich, indicaba claramente la ideología del funcionario y de una parte del gobierno: el nacionalismo representado por la bandera nacional (en el pasado los trabajadores se identificaban con la bandera roja), el sentido moralizador atribuido al trabajo, el hogar como símbolo de la tradición y la religión como factor de unidad.

El sentido de espectáculo que orientaba los festejos revela, como señala John Kraniauskas, el trabajo del "inconsciente óptico" del peronismo entendido como "sus condiciones audiovisuales y cinemáticos de existencia como formación político cultural". ${ }^{21}$ Los efectos visuales encuentran un

yo sé / Que te va a ganar mi pueblo / Porque la vas a sanar / Con el mejor de tus besos / Y ella volverá a pelear / ¡como antes...!, ¡a sangre y fuego!... / Bandera descamisada / Sobre el mástil de acero, / ¡linda, fanática y fuerte / Capitana de mi pueblo!

Jorge Mar era el seudónimo de Raúl A Mende. Nació el 11 de marzo de 1918 en Felicia (Santa $\mathrm{Fe}$ ), fue médico, escritor y funcionario. Ejerció su profesión en Esperanza, donde fue intendente municipal. Ministro de Bienestar y Seguridad Social de Santa Fe, Secretario de cultura y policía municipal de la Capital federal, Ministro de Asuntos Técnicos de la Nación y director de la Escuela Superior Peronista. Después de 1955 emigró a Paraguay. En 1959 reanudó sus actividades en Entre Ríos, luego se radicó en Buenos Aires, donde falleció el 3 de septiembre de 1963. La canción fue transcripta en El Hogar, edición del 1 de agosto de 1952 y también se publicó en Mundo Peronista (N. ${ }^{\circ}$ 8, noviembre 1 de 1951), Cancionero..., págs. 147 a 149.

19 Democracia, 2 de mayo de 1952.

20 Marcha del trabajo (Letra: Oscar Ivanissevich - Música Cátulo Castillo) Hoy es la fiesta del trabajo / Unidos por el amor de Dios / Al pie de la bandera sacrosanta / Juremos defenderla con honor. / Que es nuestro pabellón azul y blanco / La sublime expresión de nuestro amor. / Por él, por nuestros padres, por los hijos / Por el hogar que es nuestra tradición. / Se ennoblece la vida trabajando / Se quiere más la patria y el hogar / Cuando el sudor bendice nuestro esfuerzo / Cuando ganamos trabajando, el pan. / San Martín venció el Ande trabajando / Y traspuso las cumbres hacia el sol, / Cumpliendo los deberes de argentinos / Tendremos los derechos y el amor.

21 Kraniauskas, John: "Eva-peronismo, literatura, estado", en Revista de crítica cultural, 24, junio de 2002, Santiago de Chile, pág. 46. El concepto de "inconsciente óptico" lo toma de Walter Benjamin cuando señala que con el primer plano se ensancha el espacio, con el retardador se alarga el movimiento y con la ampliación se trata de aclarar lo que de otra manera no se veía claro, todo esto permite la aparición de formas estructurales nuevas. "La naturaleza que habla a la cámara no es la misma que habla al ojo", dice Benjamin, resalta que es distinta porque en el lugar del espacio tramado por el hombre con su consciencia se presenta otro tramado que es inconsciente, y concluye que "por su virtud experimentamos el inconsciente óptico igual que por medio del psicoanálisis nos enteramos del inconsciente pulsional", "La obra de arte en la época de su reproductibilidad técnica", en Discursos Interrumpidos, Planeta Agostini, pág. 48 
punto de alto impacto en el desfile de carrozas alegóricas el 1 de mayo de 1948. Ese día desfilaron diez carrozas con alegorías relacionadas a los derechos que se encuentran en la base de la justicia social. ${ }^{22}$ En el desfile respetaron el orden del decálogo de los trabajadores: I) Derecho a trabajar; II) Derecho a una retribución justa, III) Derecho a la capacitación, IV) Derecho a condiciones dignas de trabajo, V) Derecho a la preservación de la salud, VI) Derecho al bienestar, VII) Derecho a la seguridad social, VIII) Derecho a la protección de la familia, IX) Derecho al mejoramiento económico, X) Derecho a la defensa de los intereses profesionales.

Las formas que adquiere la representación varían. La carroza que encabezaba el desfile era la que simbolizaba los derechos del trabajador. El trabajador (el perfil se asemeja bastante a las imágenes que se difundían de Perón) lleva en sus manos un libro y una mano gigantesca que señala hacia delante, hacia el futuro (Fig. 5). La mano, bajo la forma de un puño inmenso y vigoroso que sostiene un martillo símbolo de la creación, se repite en la carroza que representa el "derecho a trabajar", a los costados esquemáticas figuras masculinas parecen avanzar en posición marcial (Fig. 6). La mano vuelve a reproducirse en otras figuras; por ejemplo en la carroza "Derecho a una retribución justa", allí sostiene una balanza cuyos platillos mantienen de manera equilibrada el dinero y el fruto del trabajo (Fig. 7) y en la carroza que representa la protección de la familia (Fig. 13). Las manos tienen varios sentidos: están asociadas al trabajo y a la acción; simbolizan las autoridad del padre de familia y en el sentido de representación de la autoridad, la protección y el poder pueden asociarse a la protección estatal tal como lo hace Marcela Gené..$^{23}$

Las figuras femeninas refieren a la capacitación y la preservación de la salud. Una figura con reminiscencias de estatuas clásicas sostiene la luz - símbolo de lo indestructible - y un libro - en un sentido alegoría del poder- como representación de los saberes necesarios para consolidar una idea de Argentina fuerte y poderosa (Fig. 8). La mujer-madre encarna el cuidado de la salud de la nación y de la familia (Fig. 10) . Una mujer musculosa sostiene a un niño en brazos y acompaña la imagen del trabajo representada por una figura masculina que sostiene una pala en el "derecho al bienestar" (Fig. 11).

22 Para un análisis de la iconografía y la gráfica del peronismo, Gené, Marcela Marta: Un mundo feliz. Las representaciones de los trabajadores en la propaganda del peronismo (1946-1955), Universidad de San Andrés, Buenos Aires, 2001.

23 Para las referencias a la simbología se ha utilizado Cirlot, Juan Eduardo: Diccionario de símbolos Labor, Barcelona, 1994; Gené: Un mundo..., págs. 99 y 100. 


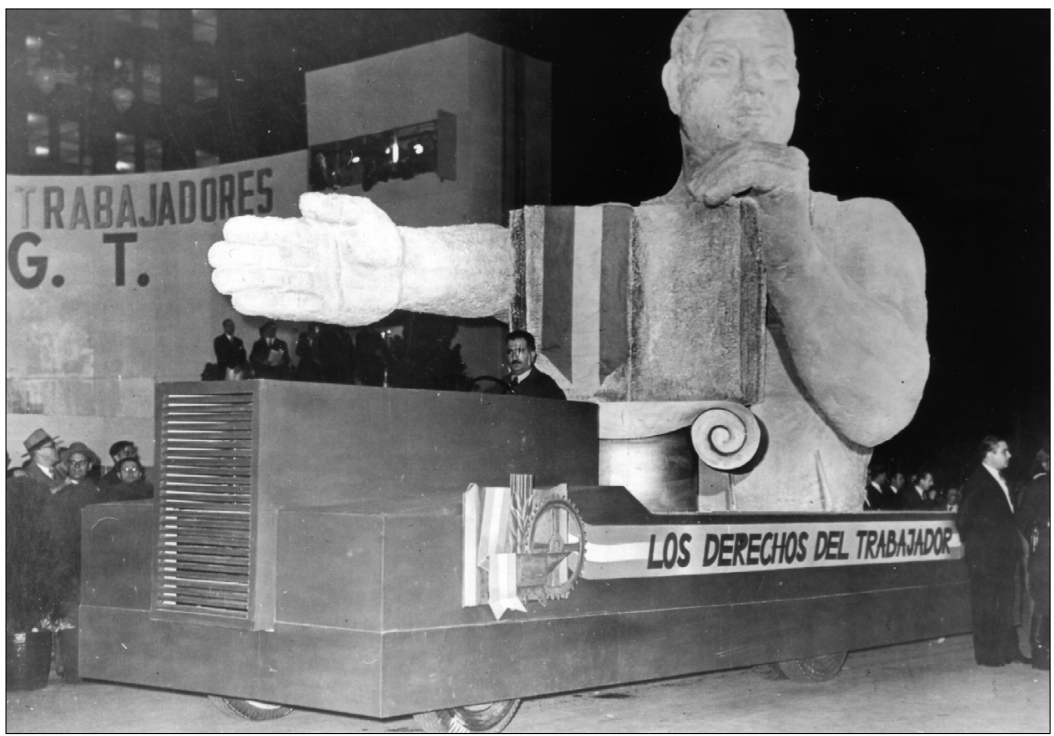

Fig. 5.-Carroza que representa los "Derechos del Trabajador", 1 de mayo de 1948, AGN.

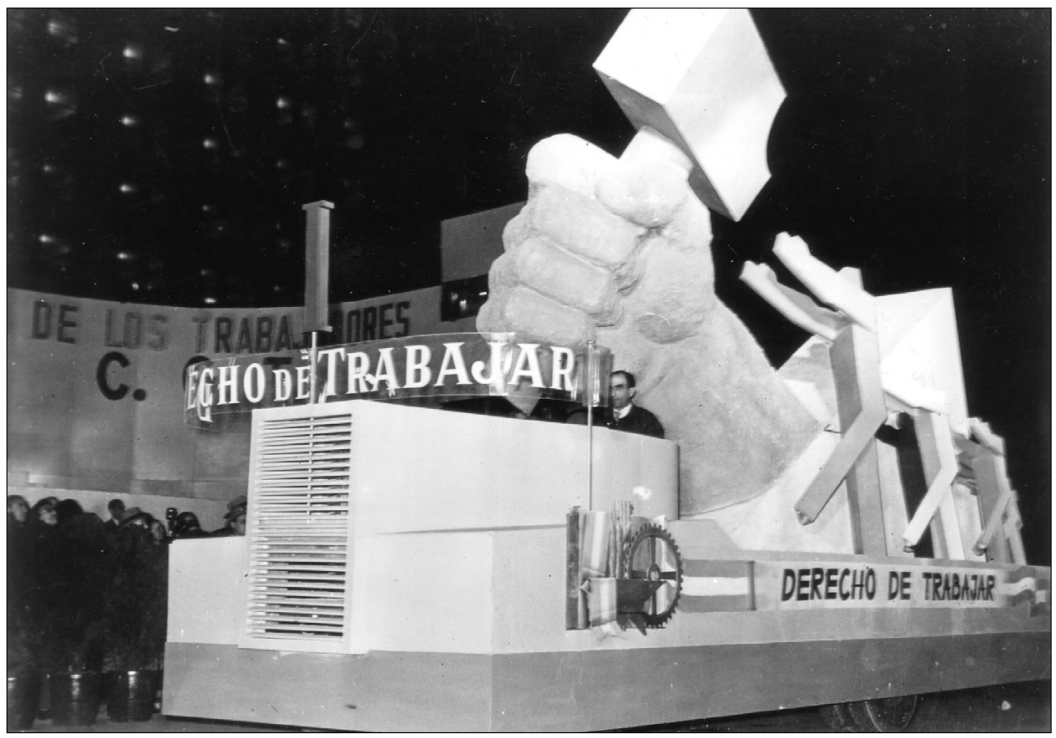

Fig. 6.-Carroza que representa el "Derecho a Trabajar", 1 de mayo de 1948, AGN. 


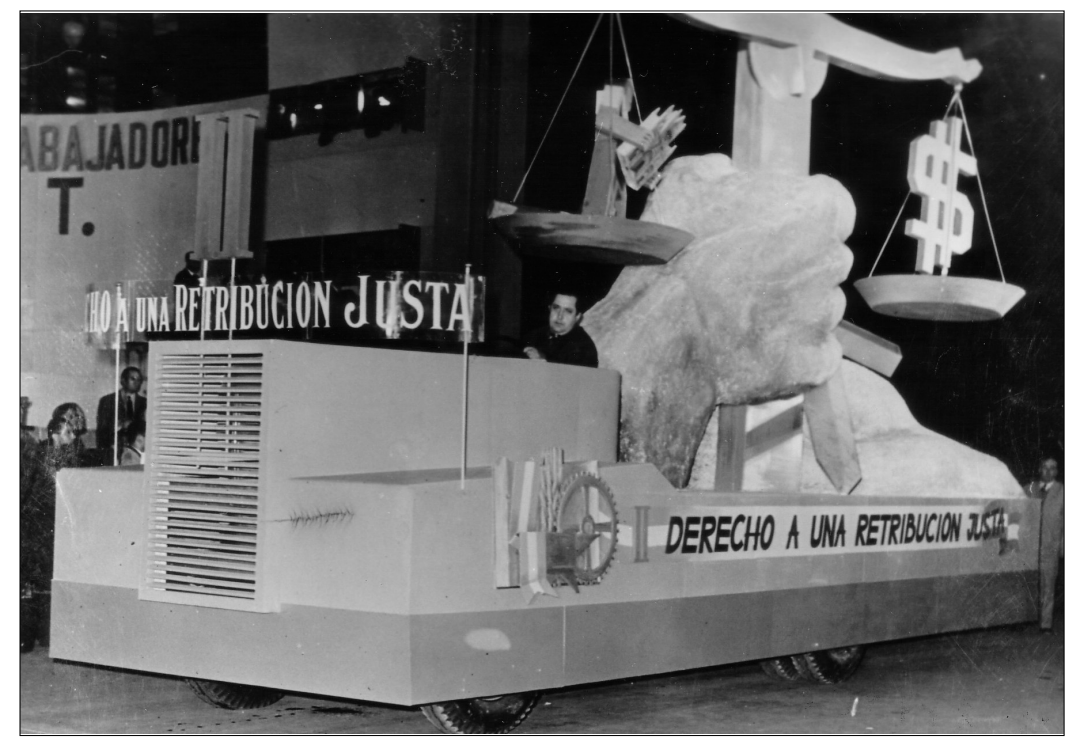

Fig. 7.-Carroza que representa el "Derecho a una Remuneración Justa", 1 de mayo de 1948, AGN.

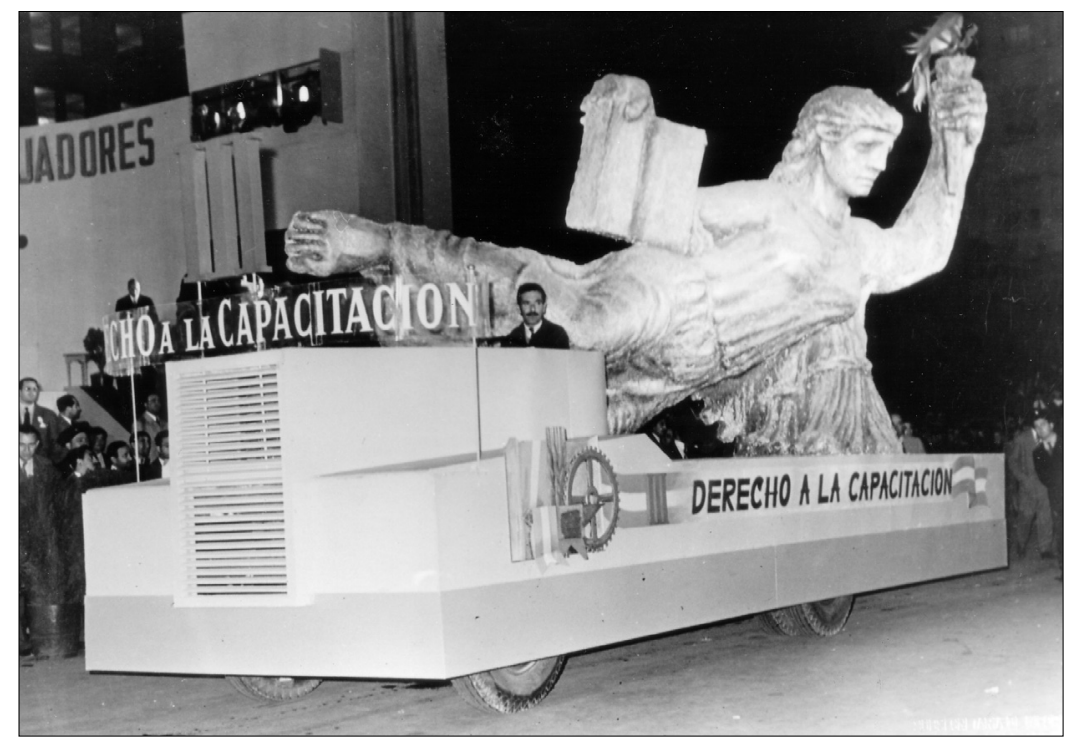

Fig. 8.-Carroza que representa el "Derecho a la Capacitación", 1 de mayo de 1948, AGN. 


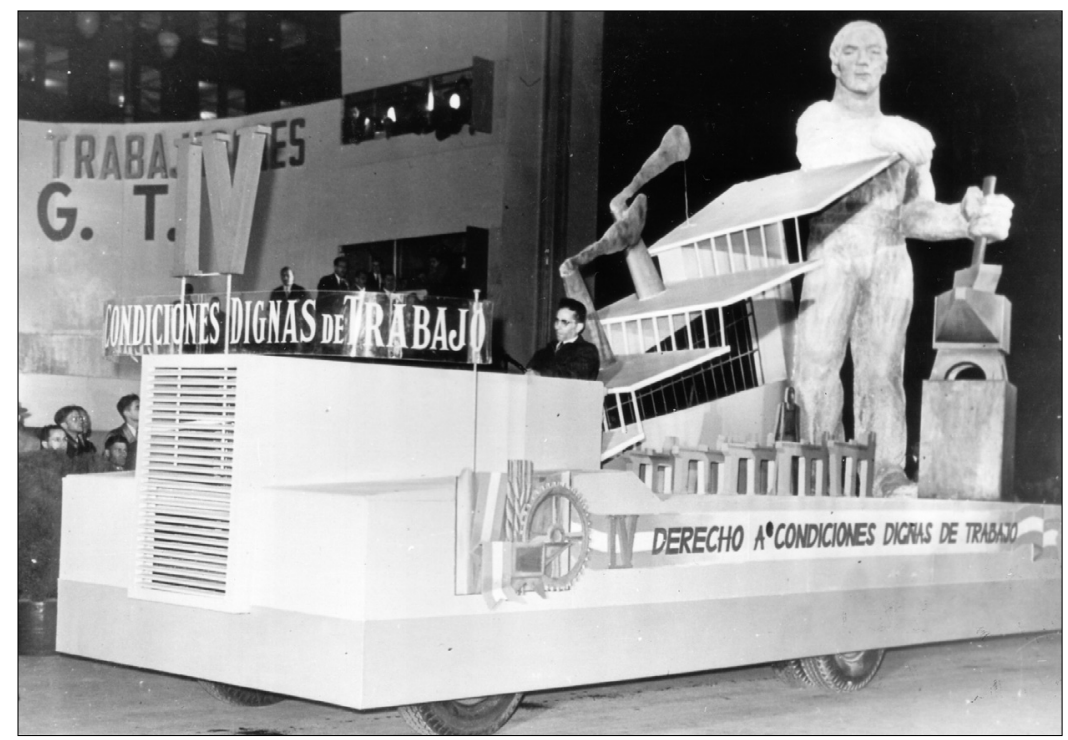

Fig. 9.-Carroza que representa el "Derecho a Condiciones Dignas de Trabajo", 1 de mayo de 1948, AGN.

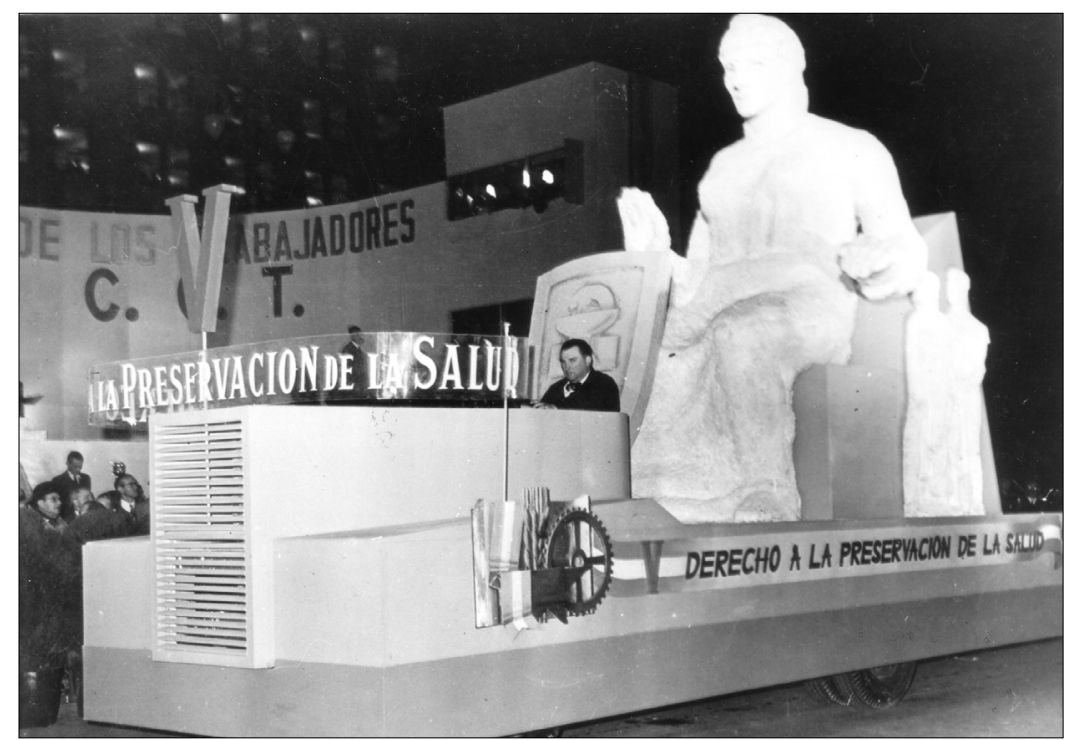

Fig. 10.-Carroza que representa el "Derecho a la Preservación de la Salud", 1 de mayo de 1948, AGN. 


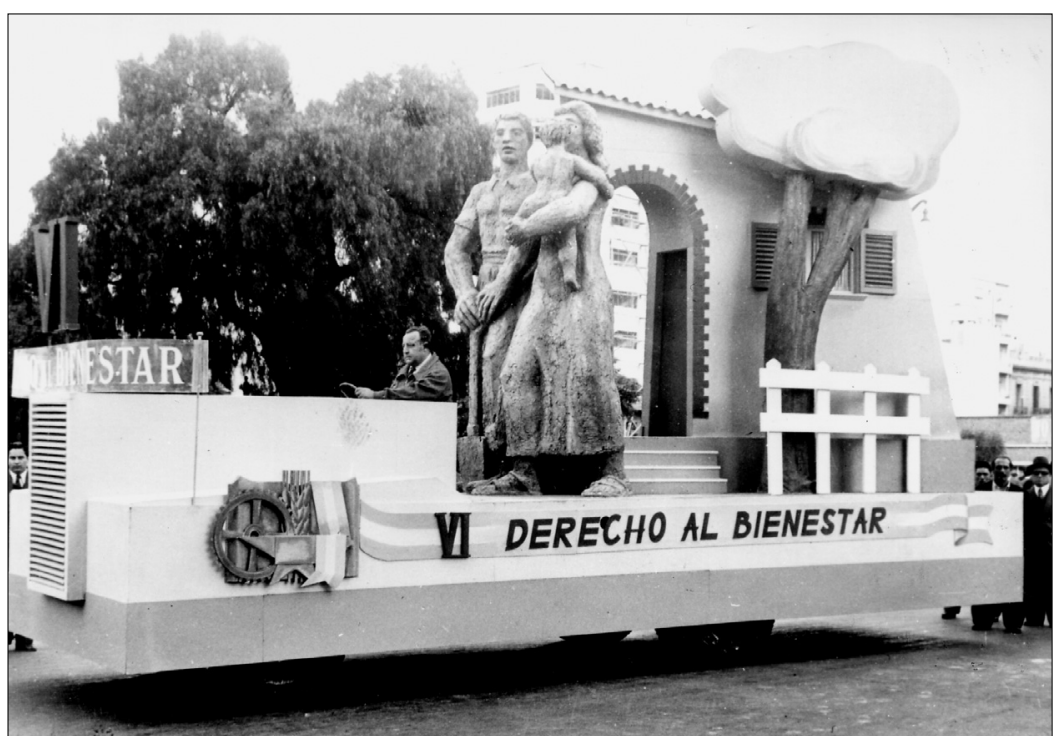

Fig. 11.-Carroza que representa el "Derecho al Bienestar", 1 de mayo de 1948, AGN.

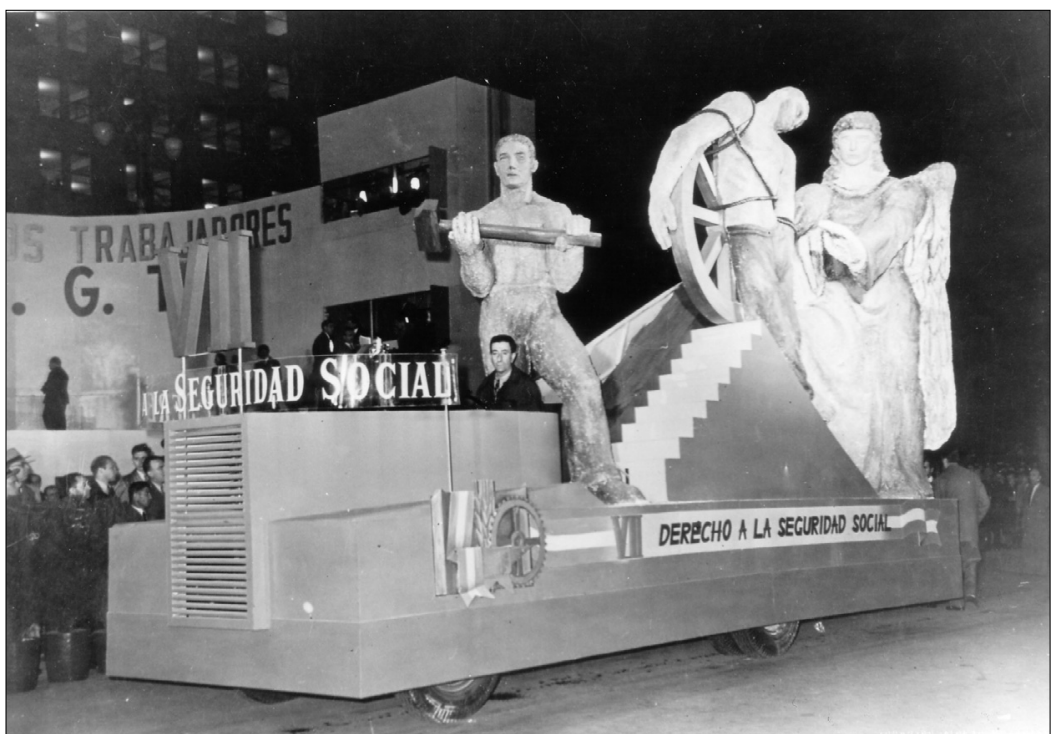

Fig. 12.-Carroza que representa el "Derecho a la Seguridad Social", 1 de mayo de 1948, AGN. 


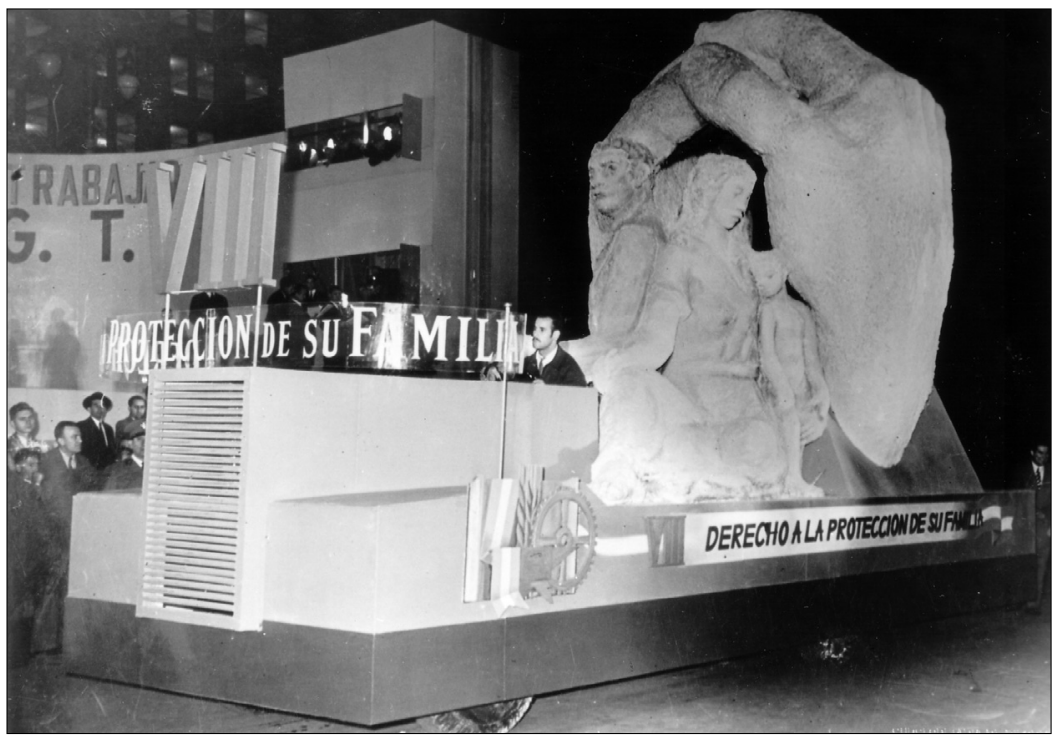

Fig. 13.-Carroza que representa el "Derecho a la Protección de la Familia", 1 de mayo de 1948, AGN.

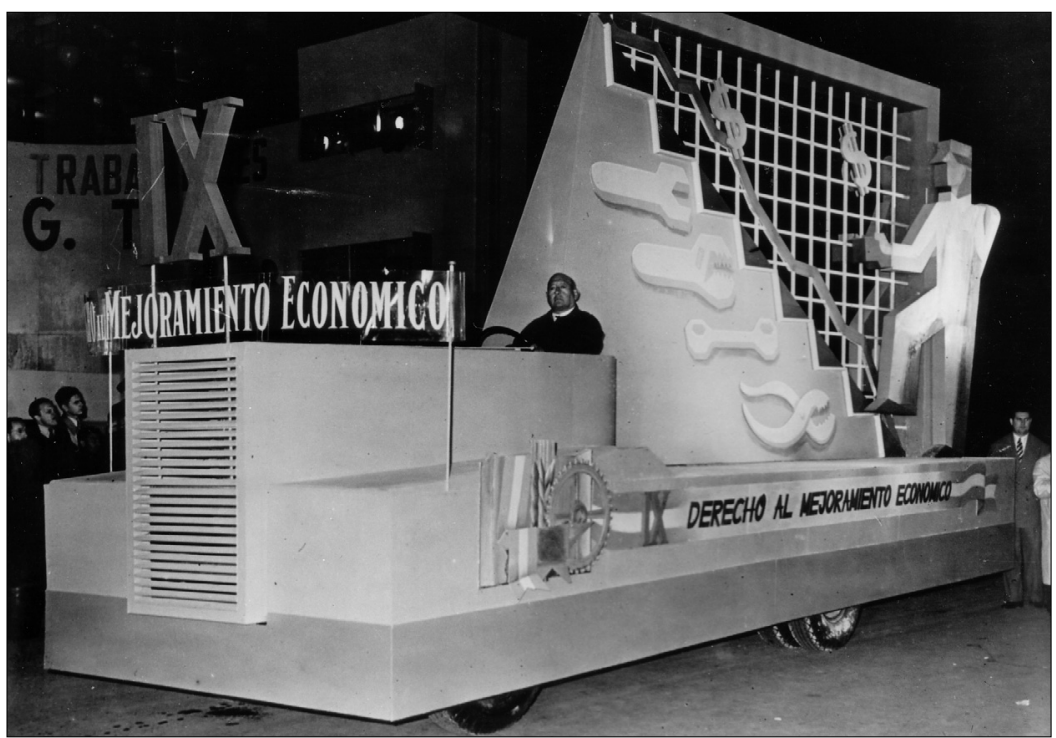

Fig. 14.-Carroza que representa el "Derecho al Mejoramiento Económico", 1 de mayo de 1948, AGN. 


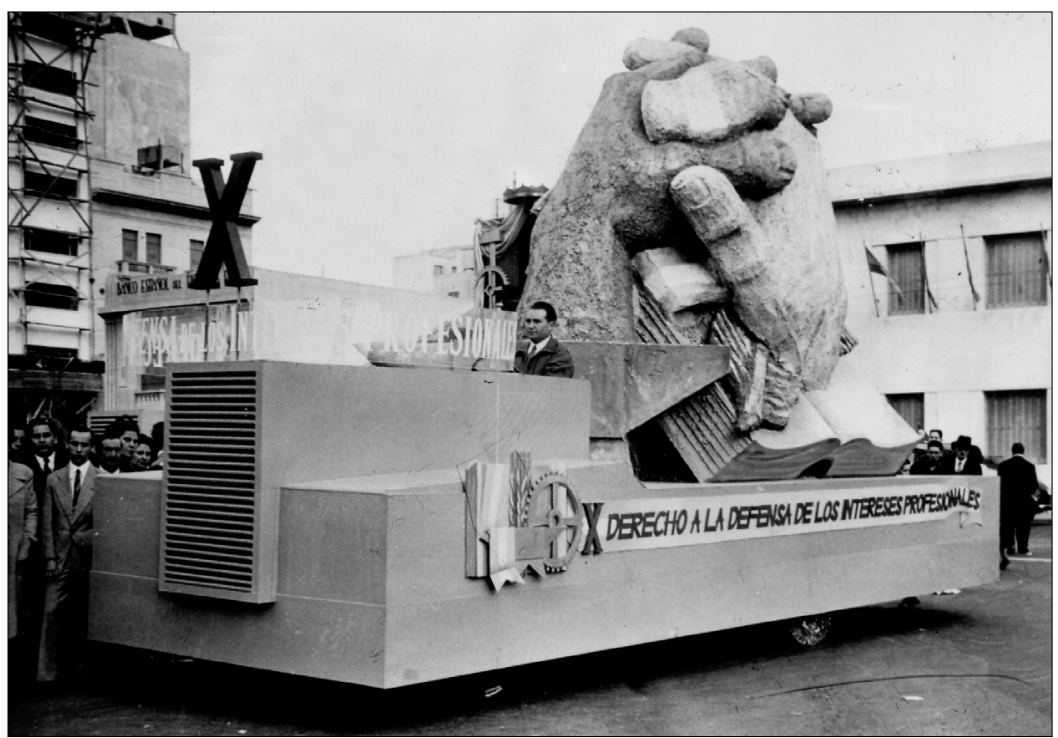

Fig. 15.-Carroza que representa el "Derecho a la Defensa de los Intereses Económicos", 1 de mayo de 1948, AGN.

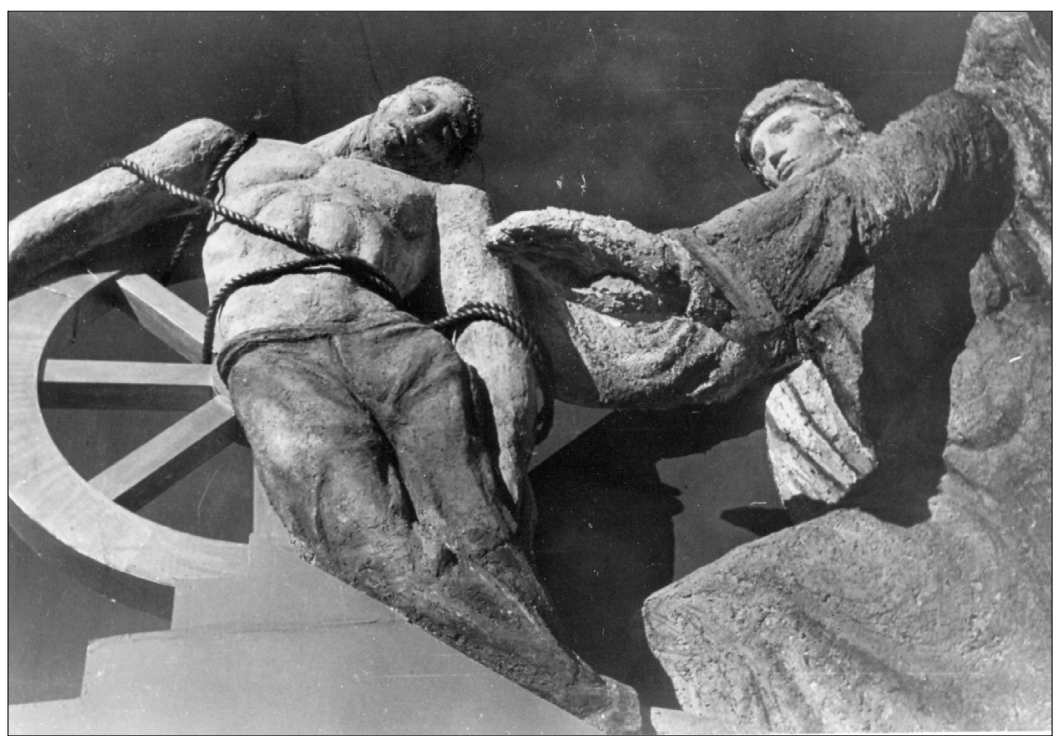

Fig. 16.-Figura alegórica de la carroza que representa el "Derecho a la Seguridad Social", 1 de mayo de 1948, AGN. 
La escenografía de las carrozas, como la del escenario, es compleja pues tiene varios espacios, planos y representaciones. Los espectadores pueden contemplar diferentes escenas de acuerdo a la posición en la que se encuentran. Desde un ángulo observan la representación de la inseguridad de la vida obrera con las figuras amarradas a una rueda como clara alusión a la explotación de la que eran objeto los trabajadores en el pasado, al mismo tiempo pueden mirar la figura de un ángel que anuncia el presente de liberación que significa la etapa inaugurada por Perón (Fig. 12 y 16). Desde un punto de vista religioso dentro de la tradición cristiana el ángel se asocia también con la protección. Además es posible observar una figura masculina con un martillo en su mano, que está libre del peligro y de las ataduras de la explotación. (Fig. 12). ${ }^{24} \mathrm{El}$ martillo es la herramienta clásica del herrero y está fuertemente asociada a la creación.

Banderas, figuras alegóricas colosales, cantos constituían la escenografía imaginada por funcionarios como Oscar Ivannisevich y José María Castiñeira de Dios y plasmada en bocetos y estudios de arquitectos como los de Guillermo Kisser con la colaboración de Diego Luis Pedreira, escenógrafo y profesor de la Escuela de Bellas Artes. El trabajo de la fabricación de las figuras y el montaje de las carrozas se realizaba en los talleres ubicados en diferentes partes de la ciudad. Allí se ampliaban bocetos, se hacía la tapicería, la costura, los trabajos de herrería y carpintería. Las figuras eran ejecutadas por escultores con una larga trayectoria en los talleres de escenografía del Teatro Colón. La institución que organizaba y materializaba todo los trabajos necesarios era la Sección de Festejos y Ornamentaciones de la Municipalidad de Buenos Aires. ${ }^{25}$

Del conjunto de carrozas alegóricas nos interesa destacar las formas que toma la representación de la mujer. Las figuras no constituyen una imagen de ruptura del papel atribuido a la mujer: madre protectora y responsable del hogar y de la familia y compañera del varón. Estas imágenes eran acordes con la ideología formal del peronismo y con las tradiciones iconográficas y discursivas que se habían formulado desde fines del siglo XIX sobre los roles femeninos, y que compartían diversas y contrapuestas corrientes ideológicas como el socialismo, el anarquismo y el catolicismo. ${ }^{26}$

24 Gené: Un mundo..., pág. 97.

25 Gené: Un mundo..., pág. 102.

26 Lobato, Mirta Zaida: "Entre la protección y la exclusión. Discurso maternal y protección de la mujer obrera, Argentina 1890-1934", en Suriano, Juan (compilador): La cuestión social en Argentina, 1870-1943, Manantial, Buenos Aires, 2000. 


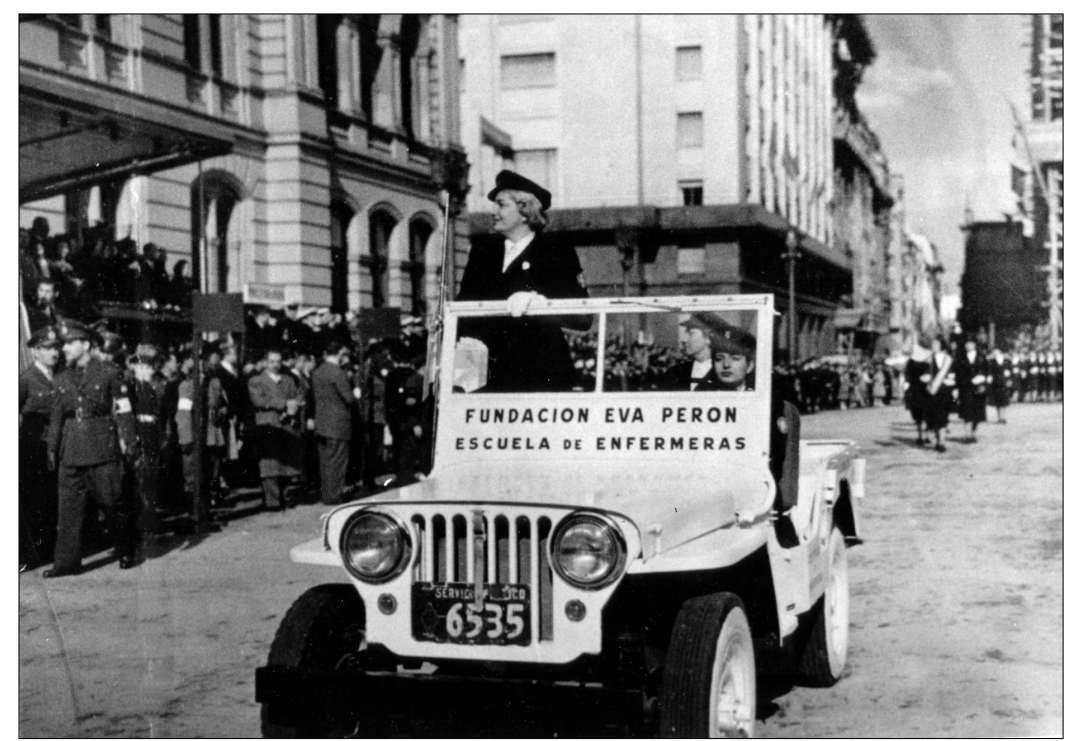

Fig. 17.—Enfermeras desfilando, Archivo del diario La Razón, s.f.

Es interesante señalar que la iconografía de la mujer durante el peronismo se apoya en la profusión de imágenes hogareñas, de mujeres sentadas frente a una máquina de coser, recibiendo al esposo cuando regresaba de su trabajo o despidiendo a los niños rumbo a la escuela. El hogar, apacible, ordenado, armónico era el "lugar" de la mujer y ella estaba dispuesta a realizar enormes esfuerzos por los otros. Su abnegación y altruismo se sublimaba en la figura de la enfermera (Fig. 17). Pero acorde con el discurso industrializador del peronismo, la imagen por excelencia en afiches de propaganda, folletos e incluso en los cortos publicitarios de cine es la figura masculina vestida de overall que representa al trabajador urbano industrial. Esta imagen compite con la representación del descamisado, símbolo del proceso disruptivo que había protagonizado el pueblo el 17 de octubre de $1945 .{ }^{27}$

27 Las representaciones de la mujer bajo el peronismo fueron examinadas por Navarro, Marysa: Evita, Corregidor, Buenos Aires, 1981; Bianchi, Susana, y Sanchís, Norma: El Partido peronista femenino, Ceal, Buenos Aires, 1988; sobre la figura del descamisado ella aparece en los análisis sobre el 17 de octubre compilados por Torre, Juan Carlos: 17 de octubre de 1945, Ariel, Buenos Aires, 1995, y respecto a la iconografía Gené: Un mundo..., págs. 129-139. 
El análisis de las representaciones iconográficas del peronismo sobre los trabajadores revela que ella se alimentó del conjunto de imágenes disponibles en la tradición socialista y anarquista del pasado, de las que se apropiaron selectivamente y a las que dotaron de nuevos sentidos. Marcela Gené señala que la figura del trabajador se desdobla en tres versiones: el descamisado como representación de la heroicidad del pueblo; el trabajador industrial como referente de las fuerzas productivas y como hombre de carne y hueso en el marco de la familia. La representación dominante es masculina y las mujeres trabajadoras sólo parecen corporeizarse en la figura de la enfermera.

Sin embargo, las fotografías de las "reinas del trabajo" difunden una imagen distinta a la de la iconografía gráfica, que podría denominarse tradicional, del peronismo sobre trabajadoras y sobre las mujeres. ¿Qué expresa el inconsciente óptico del peronismo a través de estas imágenes?

El espectáculo generaba una intensa movilización de público. Las fotografías de 1948 son elocuentes respecto a la presencia de la multitud. Rodeaban a las carrozas, entorpecían su paso, todos querían ver a las "bellezas argentinas". La policía debía intervenir para evitar que la multitud hiciera más lento el desarrollo de las actividades programadas (Fig. 31).

La movilización comenzaba temprano. Los periódicos, sobre todo los más fervorosos defensores del gobierno, describen los contingentes de trabajadores trasladándose hacia las calles donde se realizaría el desfile y hacia la Plaza de Mayo. En 1949 las muchedumbres obreras llegaron en trenes ordinarios y convoyes especiales. Por la tarde, temprano, la multitud ya se había reunido frente al palco levantado en Rivadavia y Balcarce. Con el objetivo de llegar a la Plaza de Mayo, las columnas de trabajadores se iban concentrando en las Plaza Miserere y de Constitución y en los parques del Retiro. Las columnas organizadas por la CGT se identificaban con los carteles de sus gremios. Por todas partes se escuchaban las canciones que comenzaron a convertirse en parte de la liturgia peronista: Canto al trabajo (se había popularizado el año anterior) y las marchas Los muchachos peronistas y La dama de la esperanza.$^{28}$ Esta movilización se repetía cada año.

\section{Las reinas del trabajo}

Las elecciones de las reinas implicaban un largo proceso, al final del cual la mujer más bella era elegida representante provincial/regional del

28 La Razón, 2 de mayo de 1949. 
trabajo y, finalmente, en la ceremonia del 1 de mayo reina nacional. ¿Quiénes eran las soberanas? ¿Cómo eran seleccionadas? ¿Cuáles eran sus aspiraciones?

El proceso de selección parece haber ido modificándose a lo largo del tiempo. Al principio eran jóvenes mujeres, que trabajaban generalmente como empleadas en alguna empresa de servicio, en determinada dependencia oficial o en alguna oficina sindical. Las obreras de fábricas y talleres fueron escasas en número, aunque cada 1 de mayo varios sindicatos elegían sus soberanas. ${ }^{29}$ No obstante una de las reinas nacionales era según la prensa representante del Sindicato de Oficios Varios de la provincia Eva Perón. Las reinas eran mujeres jóvenes, sus edades oscilaban entre 15 y 20 años, y para la fiesta nacional llegaban a la ciudad de Buenos Aires desde los pueblos y ciudades del interior, visitaban algunas fábricas, eran agasajadas en algunos gremios, el ferroviario por ejemplo, y en los periódicos y revistas peronistas (Democracia, El Líder, Mundo Peronista).

Las bellas mujeres se ubicaban en una parte importante del escenario que se montaba para el desarrollo de la "fiesta" (Fig. 18). En unas gradas ascendentes se ubicaban las candidatas vestidas de gala, con capa, corona y cetro. El cetro representa tanto una vara mágica, el rayo, el falo, pero su simbología está acrecentada con el remate en un engranaje industrial similar al utilizado por la Confederación General del Trabajo (CGT). Los gestos eran ampulosos. En 1948, poco después del desfile de las carrozas alegóricas, algunos toques de clarín solicitaron silencio a la muchedumbre, en ese momento se anunció la llegada de la carroza que conducía a las reinas regionales del trabajo. Cuando la carroza llegó a la gran escalinata que daba al "proscenio" varios "pajes" se adelantaron y las precedieron a los lugares que les habían reservado (Fig. 19). Terminada la ceremonia de la coronación, el cuerpo de baile del Teatro Colón realizó un desfile simbólico de mujeres trabajadoras, y cuando Perón le habló a la multitud señaló: “... Compañeros, que sea ésta la fiesta por antonomasia del pueblo argentino. Por esta razón, el gobierno que es pueblo puro; el gobierno que se siente honrado de llamarse a sí mismo de trabajadores, inaugura esta fiesta bajo los auspicios de ese pueblo descamisado, lleno de mérito para la Patria; inaugura esta fiesta, alegrada y adornada por la representación de la mujer argentina, cuya síntesis tenemos que mirar en las reinas de las distintas

29 Por ejemplo, en el periódico gremial El trabajador de la carne se publica la foto de una bella mujer con una nota que dice: "La señorita Alba E. Pazos que representó a nuestro gremio en el Certamen Nacional de belleza organizado por la CGT", Buenos Aires, Mayo-junio de 1954, Año II, n. 44-45. 


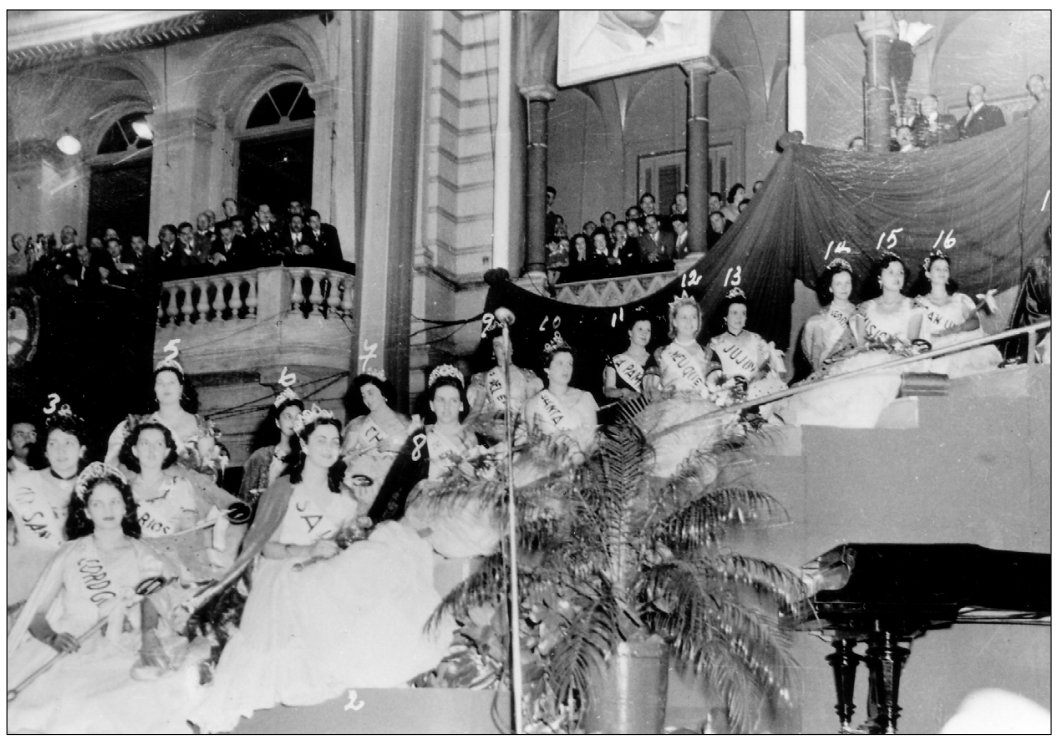

Fig. 18.--Reinas del trabajo, 1 de mayo de 19950, AGN.

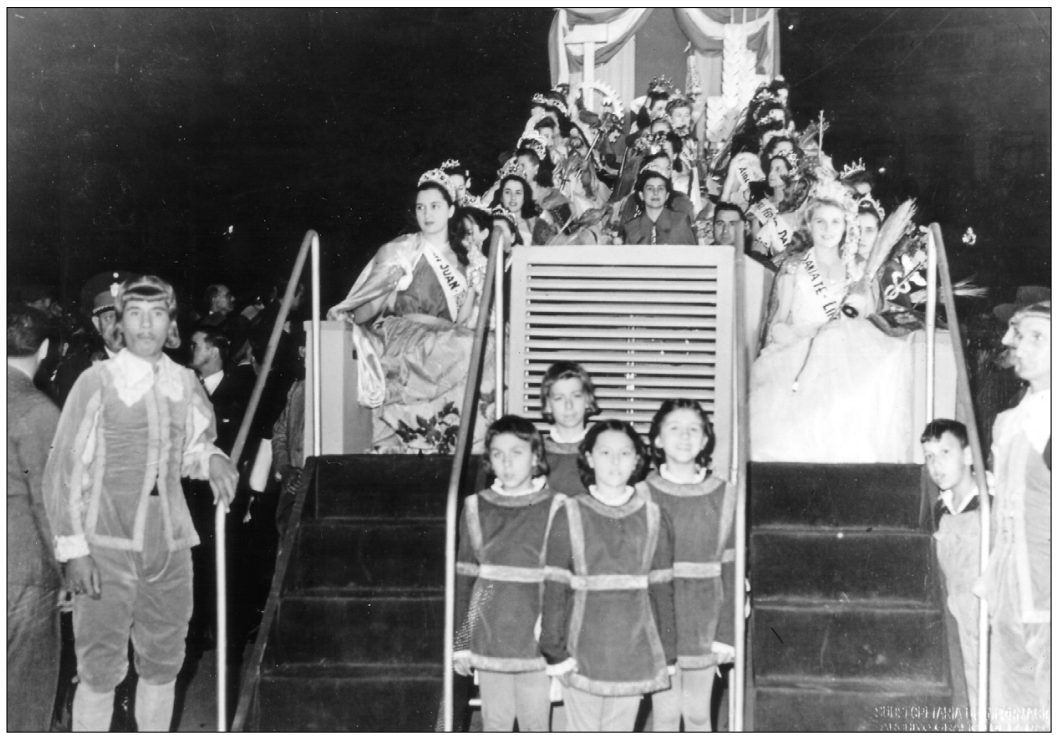

Fig. 19, Varios pajes reciben a las reinas del trabajo, 1 de mayo de 1948, AGN. 
actividades del trabajo de la República. Que esa belleza de nuestra tierra, representada por nuestras mujeres, constituya el augurio feliz de miles de primeros de mayo en que se encuentren hermanados y unidos, como hoy, todos los argentinos" ${ }^{30}$ La fiesta estaba ornada por la belleza de la mujer argentina y ella era la viva imagen de un augurio de felicidad. Las jóvenes de quienes se resaltaba la intensidad de la mirada, la fresca sonrisa o la cabellera (negra) representaban un ideal de mujer.

Un poema publicado en el periódico El Laborista puede ayudarnos a precisar el papel de la belleza en el ritual del 1 de mayo:

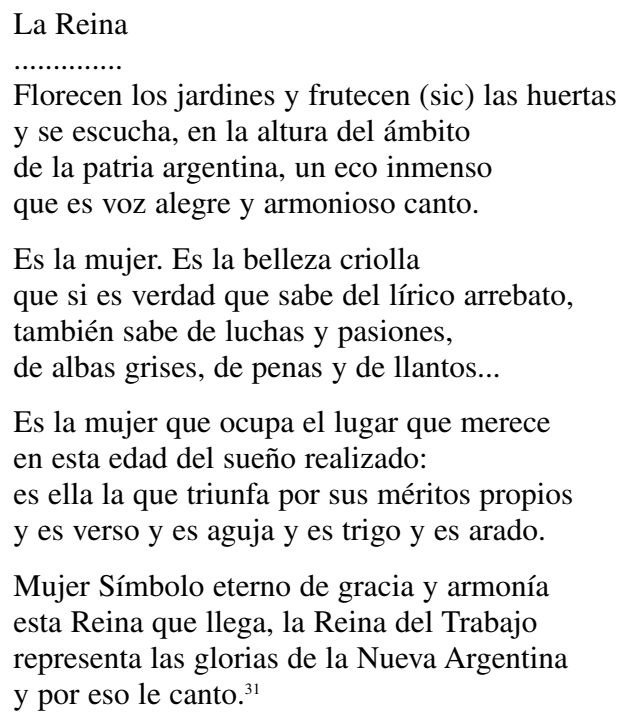

Belleza criolla, mujer símbolo, llena de gracia y armonía son las expresiones que definen a las mujeres elegidas como reinas. En el proceso de selección de las soberanas el ideal de belleza femenina y la ideología peronista están estrechamente entrelazadas y envueltas por la noción de armonía, tan difundida durante este período. Esa noción extendía su brazo sobre el conjunto "real": las mujeres como las carrozas que desfilaban por diversas calles céntricas de la ciudad, eran "un conjunto de armonía, color y belleza". 32

30 La Razón, 2 de mayo de 1948.

31 Poema de Pancho Netria dedicado a la primera reina nacional del trabajo, previamente elegida como reina de la flor y del perfume de la provincia de Buenos Aires. El laborista, 2 de Mayo de 1948.

32 El laborista, 3 de Mayo de 1948. 
A través de la exhibición pública de la belleza de la mujer trabajadora se realiza una operación ideológica que, junto a la dignificación del trabajo, vehicula una idea alrededor del requisito de belleza femenina. Las reinas del trabajo son la imagen viva del trabajo digno, que está lejos del trabajo humillante del pasado y del que deforma a la mujer (y a su prole), popularizada por la literatura, y abre el camino hacia la gloria y el reconocimiento público. La figura de la reina del trabajo encarna la combinación perfecta entre la cualidad de trabajadora y la de mujer bella, que por décadas fueron consideradas como incompatibles.

Las elegidas podían dedicarse a cualquier oficio o actividad: Ruth Romero, reina de trabajo de 1949, ayudaba a sus padres en las labores del campo y al mismo tiempo estudiaba economía doméstica y música; Práxedes Mesconi, reina del año 1950, era empleada pública; mientras que Aída Beaumé, que la sucedió, se dedicaba a las tareas domésticas; Edna Alicia Constantini, reina del trabajo de 1952, era modista después de haber estudiado corte y confección; las reinas de los años 1953 y 1954, Nélida María Ferreyra y Susana Leiva respectivamente, pertenecían a la Unión Argentina de Artistas y Variedades, mientras que Elsa Landaburu, reina del año 1955, representaba al gremio de los telefónicos. Cualquier oficio era digno y merecía el respeto público, pero la condición indispensable para la selección de la reina del trabajo era la belleza física. Es ella la que le permite convertirse en la "fiel exponente de la laboriosidad y belleza jamás desmentidas de la mujer argentina" ${ }^{33}$ en la "auténtica representante de esa gracia y esa belleza genuina de nuestras mujeres de trabajo". ${ }^{34}$ Las reinas encarnan la belleza y el espíritu del pueblo argentino y representan a todas las mujeres que trabajan y "laboran la grandeza de la Nación". ${ }^{35}$ De esta manera, las dos cualidades de la Reina, la laboriosidad y la belleza, se entrelazan y se extienden a toda la población femenina del país.

Para entender el significado de esta "generalización", habría que analizar el ideal y los criterios de belleza requeridos para las mujeres durante los años peronistas y también quiénes eran los que legitimaban esas cualidades. En el concurso un jurado masculino, la excepción es la figura de Eva Perón, consagraba a la mujer/reina. Los miembros del secretariado de la Confederación General del Trabajo (CGT) y dirigentes gremiales, Juan Domingo Perón, el presidente de la Nación, eran las voces autorizadas. Un

33 El laborista, 3 de Mayo de 1948.

34 El laborista, 3 de Mayo de 1948.

35 Discurso de Eva Perón. La Razón, 2 de Mayo de 1950. 
solo año, el de 1948, participó también el cardenal arzobispo de Buenos Aires, Monseñor Copello.

El hecho de que el concurso para la reina del trabajo fuera organizado por la Confederación General del Trabajo (CGT), así como también el carácter general que el acto revestía como parte de los festejos del 1 de mayo probablemente condicionaran hasta cierto punto quienes podrían ser las candidatas: tenían que ser trabajadoras y provenir de familias relativamente modestas. En 1950, en un discurso pronunciado durante los actos del 1 de Mayo, Eva Perón se refirió "a las humildes muchachitas pero grandes corazones que vienen a la capital para poner una nota de espiritualidad, de amor, de alegría y de esperanza en este primero de mayo". ${ }^{36}$ Humildad, belleza, bondad son las condiciones enunciadas, a las que se podría agregar el "ser buena peronista". El carácter de mujer trabajadora de las participantes se hacía más evidente cuando las elegidas, no sólo representaban la actividad económica típica de cada provincia o zona (zafra, algodón, petróleo, vendimia), sino que pertenecían a algún gremio, incluso hubo algunas que representaron a la Unión Argentina de Artistas de la ciudad de Córdoba y de la Capital Federal respectivamente, mientras que Elsa Landamburu, reina nacional del año 1955, representaba el gremio de los telefónicos de la provincia de Buenos Aires, seccional Mar del Plata.

Si la calidad de mujer trabajadora y el origen relativamente humilde eran condiciones necesarias para la participación de las jóvenes en las primeras etapas del concurso, en su etapa final era más importante su belleza física. En general, los miembros del jurado no votaban como dirigentes gremiales, sino como hombres. La representante de las fuerzas del trabajo de Argentina no tenía que ser la más laboriosa, sino la más linda. ¿Qué nos dice esto sobre la relación de los géneros durante el primer peronismo? Por un lado, como se mencionó anteriormente, esta selección formaba parte del proceso de dignificación del trabajo a través de la exhibición de la belleza. La imagen pública de la bella trabajadora era sin duda algo novedoso, pero no excepcional. En otros países, como Chile y Brasil, también elegían sus soberanas; de hecho la reina de Chile estuvo presente en el palco oficial en $1951 .^{37}$

Las fotos de las candidatas y de las reinas revelan ciertas cualidades como más importantes. El ojo del fotógrafo se detiene en la mirada y en los ojos, en la sonrisa y en la cabellera (Fig. 20 y 21). Los cronistas de la pren-

36 Discurso de Eva Perón, La Razón, 2 de Mayo de 1950.

37 Para la fiesta del 1 de mayo de 1951 estuvo presente la Reina de Chile Olga Molina, quien asistió especialmente invitada por la señora de Perón. Democracia, 2 de mayo de 1951. 


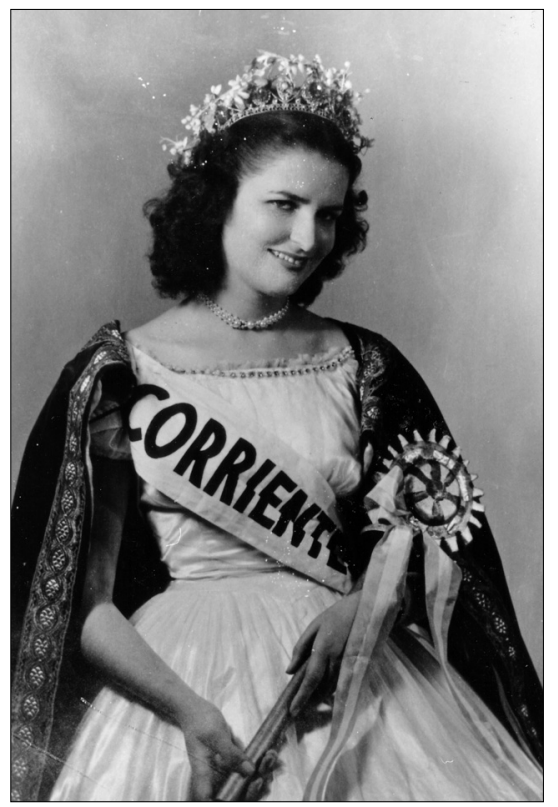

Fig. 20.-Dora Hermosa de la provincia de Corrientes, candidata a Reina Nacional del Trabajo, AGN.

Fig. 21.-Nora Civalliero de la Provincia de La Pampa, candidata a Reina Nacional del Trabajo, 1 de mayo de 1949, AGN.

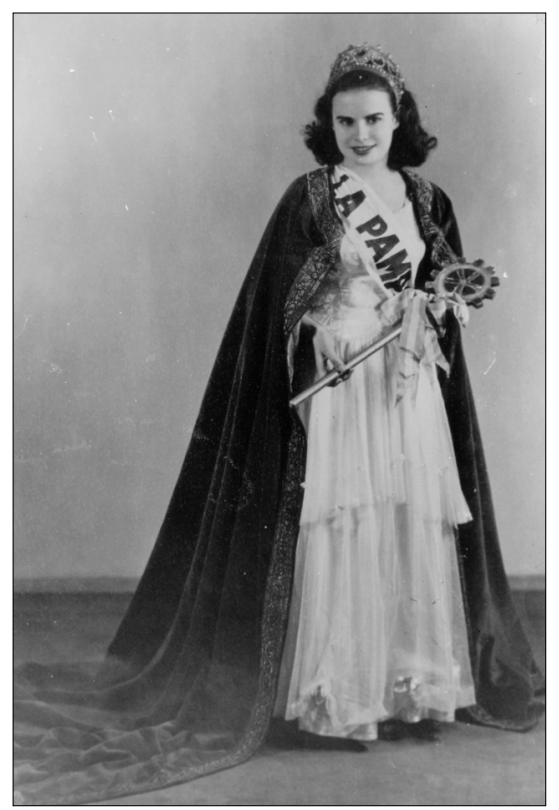


sa conducen al lector hacia la cara de las elegidas de cada año, se destacan, otra vez, sus ojos, normalmente oscuros pero siempre profundos y encendidos, la cabellera oscura, la sonrisa limpia. No abundan las referencias al cuerpo y a la ropa, aunque algunos cronistas enfatizan la suavidad del andar. ${ }^{38}$ La imagen es seriada y estereotipada: son las muchachas de las revistas de circulación masiva y de las narraciones semanales. En su análisis sobre las novelas semanales, Beatriz Sarlo señala que: "la semiótica del cuerpo (su representación literaria y gráfica) proporciona una imagen social, trabajada desde la estética y la ideología. Esta imagen social del cuerpo tiene zonas privilegiadas, hipersignificativas, zonas que se esfuman en el clarooscuro de su relativa importancia y otras directamente anuladas en el imaginario erótico colectivo. Estas redes semióticas trazan las líneas de posibilidad de una relación entre los sexos". ${ }^{39}$ Las fotografías entonces operan dentro de esa semiótica donde los ojos se convierten en la base de una sólida belleza femenina, son los mensajeros de lo que a veces no puede decirse por medio de las palabras. También hay otros rasgos de belleza valorados especialmente, los labios, la sonrisa, un lunar y en ellos se coloca una fuerte carga de atracción erótica.

En las fotografías de las reinas del trabajo su calidad de trabajadora se encubre detrás de su condición de "mujer bella universal". Juventud y naturaleza, en tanto belleza natural, se conjugan en la representación de un ideal de mujer. Se trata de una belleza "clásica" que está lejos de la "democratización estética" de nuestros días, cuando frecuentemente el "estilo" de vestir, el "tipo" o la armonía corporal se consideran, a veces, como más importantes que la belleza natural de los rasgos faciales. Los regalos ofrecidos a las elegidas durante el acto no hacen más que acentuar la condición femenina de las afortunadas: además de un broche donado por la Confederación General del Trabajo (CGT), de los atributos de la "realeza", el bastón real con el engranaje como símbolo del trabajo industrial (Fig. 22), y de cierta cantidad de dinero (gran parte de la cual se devolvía a la

38 "Quince alborozados años tiene Ruth. Quince años que juegan y saltan cuando ella ríe y que luego acurrucan los hoyuelos de las mejillas, como sorprendidos de tanto agasajo y tanta alegría. Ruth es así: ojos oscuros, profundos, de mirar ingenuo. El cabello es largo castaño oscuro, recogido hacia atrás con una redecilla. El rostro amplio, con una nariz chiquita, que tiende a irse hacia arriba y una boca franca. Un lunar diminuto, casi imperceptible pero necesario, sobre el labio superior, hacia la izquierda, completa esta belleza criolla. Ruth Socorro no es alta ni baja. La estatura ideal. Y su cuerpo, al andar tiene la suavidad y el encanto que ella le brinda con ese cuidado descuido con que se traslada de aquí hacia allá atendiendo a este y al otro, a todos". La Razón, 2 de mayo de 1949. Relatos como éste se repiten en otros periódicos y para otros años.

39 Sarlo, Beatriz: El imperio de los sentimientos, Catálogos, Buenos Aires, 1985, pág. 122. 
Fundación Eva Perón como donación), las reinas recibían brillantes alhajas que hacían lucir más su belleza.

Los textos de la prensa insisten también en características referentes a la personalidad y la moralidad de las elegidas, por ejemplo la sencillez, la modestia, la laboriosidad, el trato afable. Tales descripciones, así como también las entrevistas de las reinas publicadas en los diarios de la época, contribuían a la identificación de las demás mujeres trabajadoras con la elegida. No sólo su belleza natural, sino también su personalidad las hacía "accesibles" al gran público femenino. Las reinas de la belleza eran más lindas que las otras mujeres trabajadoras, pero no eran tan grandes las diferencias en otros aspectos. Soñaban con ser esposas y madres, no querían ser estrellas de cine, lloraban al escuchar su nombre pronunciado por los altoparlantes, el corazón les latía aceleradamente durante el concurso, no estaban acostumbradas a las luces de los flashes fotográficos. Eran reinas del trabajo y eran conscientes de que representaban a las fuerzas del trabajo, pero ante todo querían ser "reinas de su hogar".

Las soberanas eran el centro de las miradas: las del jurado, de los espectadores, de los periodistas. Eran glorificadas y admiradas en su sencillez, en su belleza y en su deseo de convertirse en esposas y madres. Ruth Sesma Romero (Tucumán), "no tiene novio... estudia labores, economía doméstica y música"..$^{40}$ Práxedes Mesconi (Salta) dijo en un reportaje: "...quiero casarme, tener un hogar y muchos hijos, para engrandecer esta Patria de Perón”. ${ }^{41}$ Edna Alicia Constantini (Quemú-Quemú, provincia Eva Perón) expresó que "su sueño es sólo un muchacho trabajador, honesto, desinteresado, que la quiera mucho y que pueda mantener un hogar feliz". ${ }^{42}$ En 1954, Susana Leiva (Capital Federal), que luego fue conocida en el mundo artístico como Susy Leiva, también enfatizaba su deseo: "Soy, como ya saben, artista de variedades. Trabajo con fe y entusiasmo. Me gusta el cine, sí, pero desde la platea. Tengo novio y pronto nos casaremos...". ${ }^{43}$ La última Reina del Trabajo del primer peronismo, Elsa Landaburu (Mar del Plata, provincia de Buenos Aires), señaló cuando le preguntaron sobre su futuro: "Espero pasarlo tranquilamente, trabajando en mi puesto de Teléfonos del Estado y preparándome para mi vida de casada". ${ }^{44}$ Las aspiraciones de las

40 La Razón, 2 de mayo de 1949.

41 Democracia, 4 de mayo de 1950. (El destacado es nuestro).

42 La Razón, 2 de mayo de 1952. (El destacado es nuestro).

43 Democracia, 2 de mayo de 1954.

44 La Razón, 2 de mayo de 1955. 
reinas se reiteran hasta el cansancio: casarse, tener hijos, formar un hogar, ser un ama de casa eficiente, para lo cual estudian labores, economía doméstica, saben coser, cocinar y limpiar la casa.

Sobre este discurso de repetición, que la prensa de la época difundía, se observan algunos indicios que expresan tensiones entre lo que se dice y los deseos probablemente inconfesables. Las notas publicadas en dos periódicos, Democracia y La Razón, en 1951, ayudan a mostrar ese cuadro de tensiones sugerida por la imagen de la joven que se mueve para convertirse en visible durante la elección de 1949 (Fig. 22). En el periódico Democracia se señala que Aída Beaumé (Capital Federal) "tiene novio y no se dedicará al cine... no piensa dejarse llevar por la tentación cinematográfica y teatral. Está esperando que su novio termine su carrera para casarse y convertirse en una esposa feliz y en una buena ama de casa" ${ }^{45} \mathrm{La}$ Razón enfatiza: "Aída, más cautivante que la de Verdi, es Reina del Trabajo: su aspiración es tener hijos y ser ángel de su casa. ... Al hablar hoy con ella volvimos a insistir acerca del noviazgo. Le hicimos notar que todas las muchachas bellas, cuando la ocasión se les presenta - y esta es una ocasión para una Aída más cautivante que la de Verdi- hablan de sus deseos de incorporarse al cine, al teatro o a la radio.

- Yo no. No puedo cambiar de parecer en dos días. Estoy de novia... nos casaremos. Mi suprema aspiración es tener un hogar e hijos... agrega que si hubiera tenido oportunidad de decidir el curso de su vida habría sido abogado (sic)...

- Pero como no he podido encauzar mis aspiraciones hacia ese sueño, aprendo a bordar, a coser y cocinar. Me preparo para ser una dueña de casa eficaz". ${ }^{46}$

Parece que hay límites para el cumplimiento de los sueños y que resulta difícil romper con la uniformación del rol femenino asociado con la casa y el hogar, al menos para las mujeres de las clases populares.

Los textos de prensa que acompañan las fotos juegan con los relatos, hay un cierto aire de narración sentimental, de textos que producen felicidad, destinados a un público femenino que encuentra un canal de identificación. La belleza natural, "accesible", de las reinas y sus características morales permitirían que el resto de las mujeres trabajadoras soñara con una suerte parecida: ser elegida, coronada por Eva y por Perón (Fig. 23 y 24), abrazada por Perón y vitoreada por el público. Ese reconocimiento impli-

45 Democracia, 3 de mayo de 1951. (El destacado es nuestro).

46 La Razón, 2 de mayo de 1951. (El destacado es nuestro). 


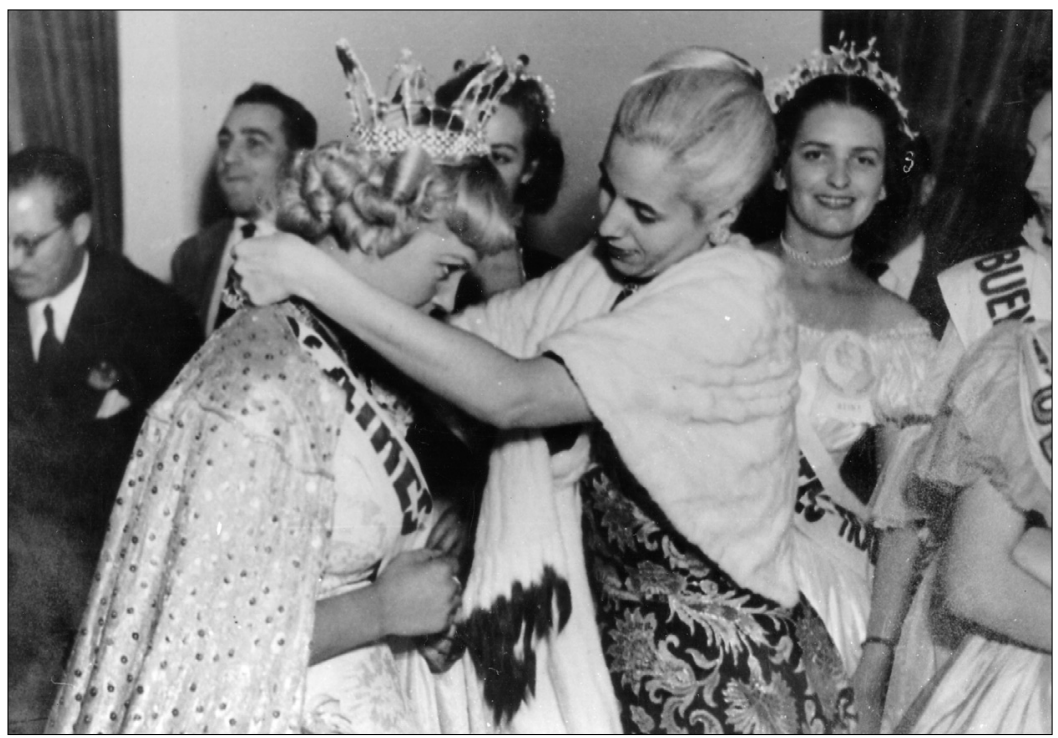

Fig. 22.-Eva Perón y las candidatas a Reina Nacional del Trabajo, 1 de mayo de 1949, AGN.

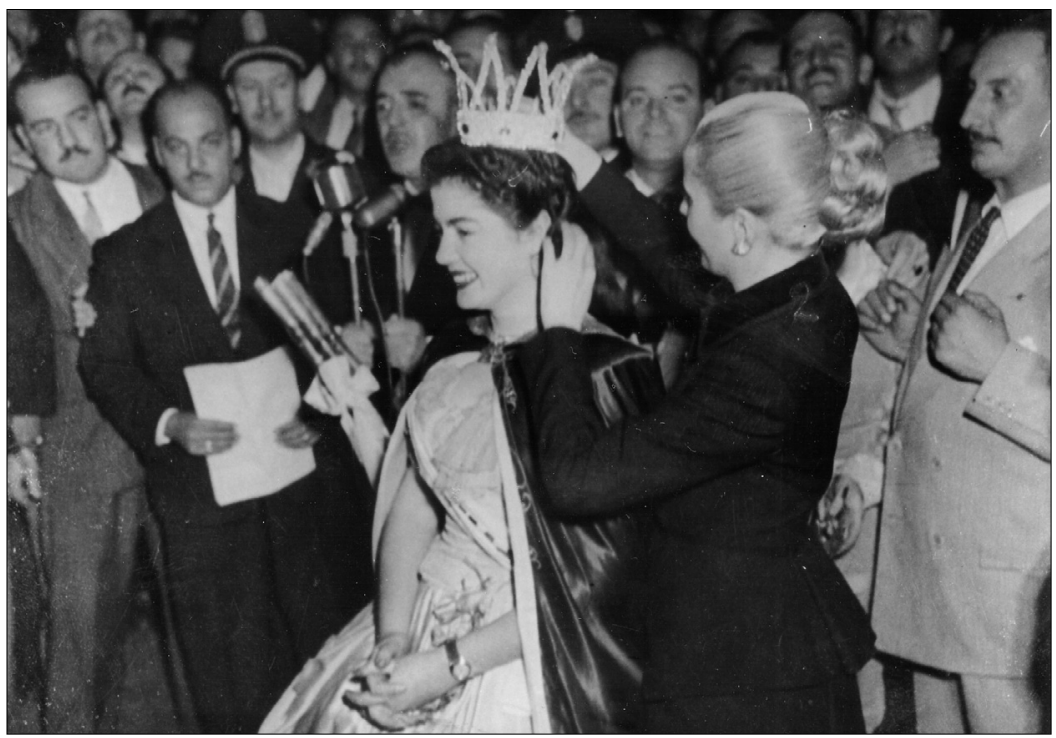

Fig. 23.-Eva Perón corona a la Reina Nacional del Trabajo de 1949, 1 de mayo de 1949, AGN. 


\section{LAS REINAS DEL TRABAJO DURANTE EL PERONISMO}

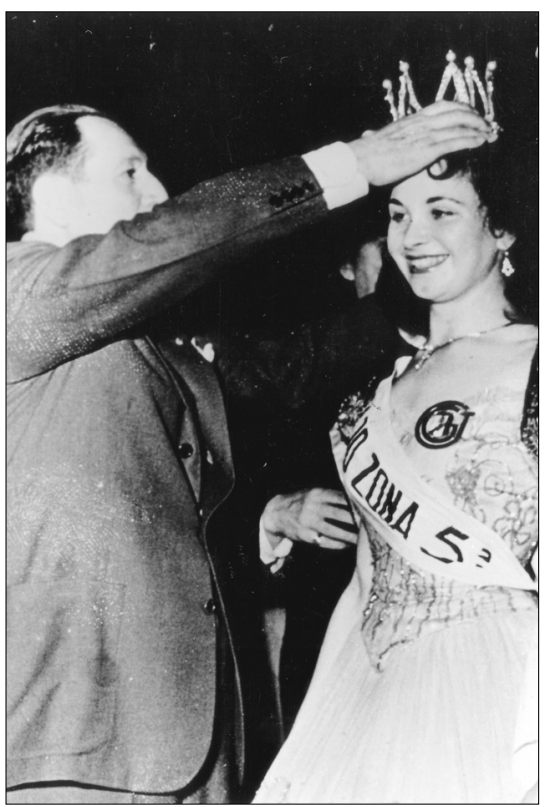

Fig. 24.- Juan Domingo Perón corona a la Reina Nacional del Trabajo de 1955, 1 de mayo de 1955, AGN.

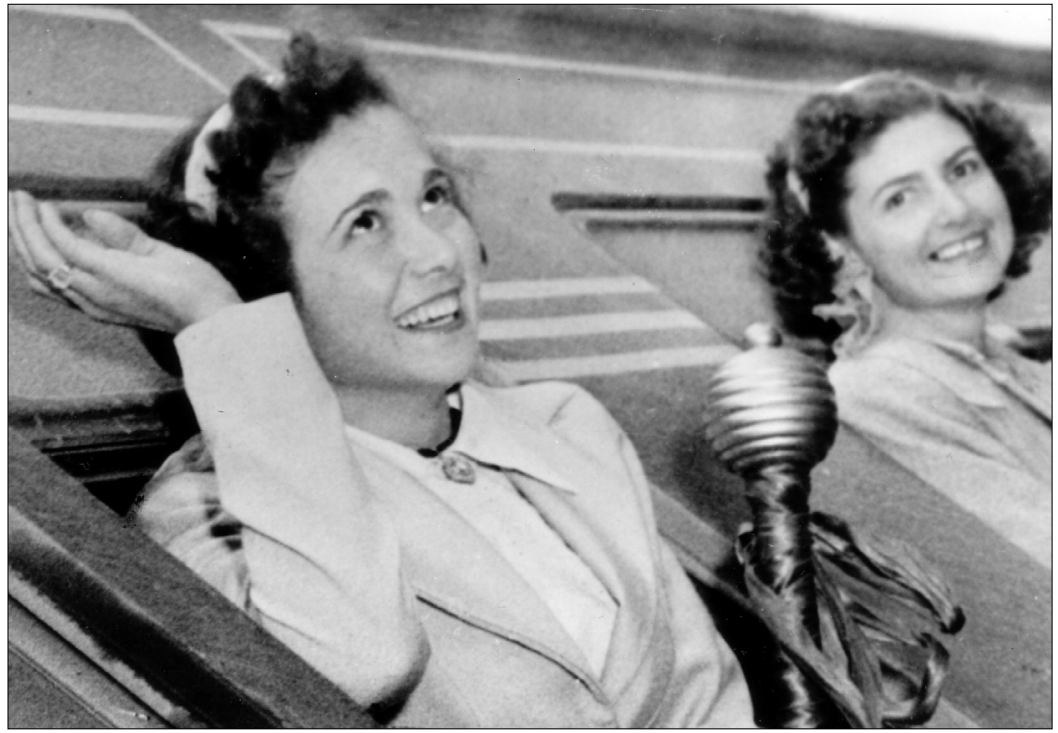

Fig. 25.- Representantes regionales y provinciales llegan a la ciudad de Buenos Aires, 1950, AGN. 


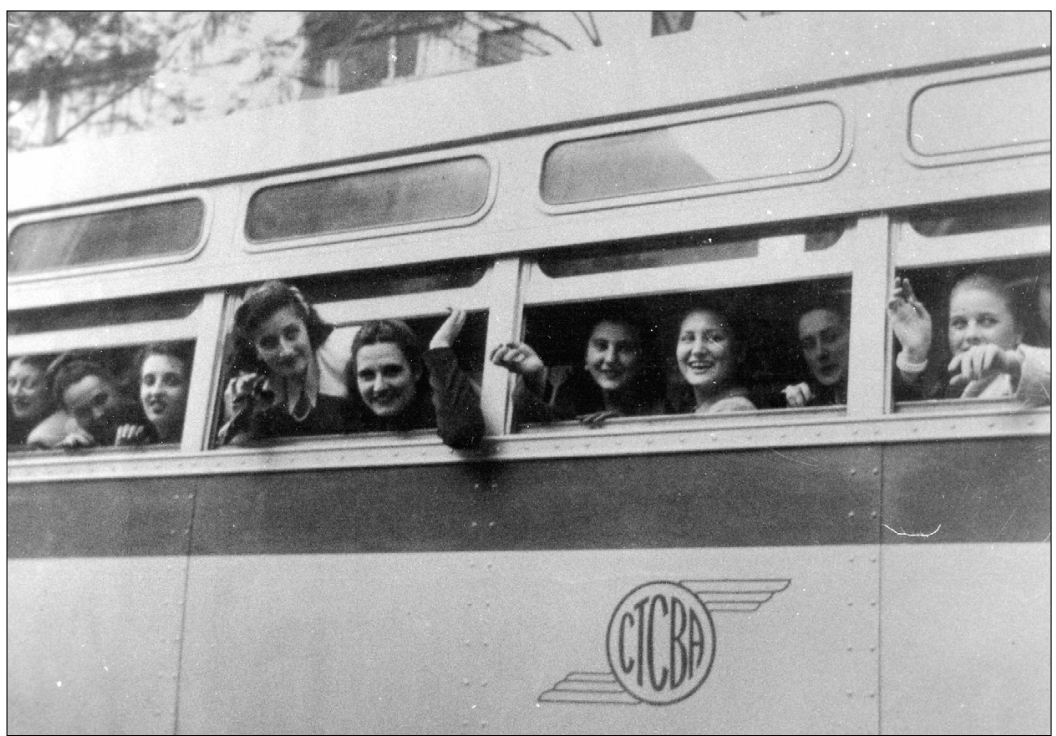

Fig. 26.-Candidatas a Reina Nacional del Trabajo pasean por la ciudad de Buenos Aires, diario La Razón, s.f.

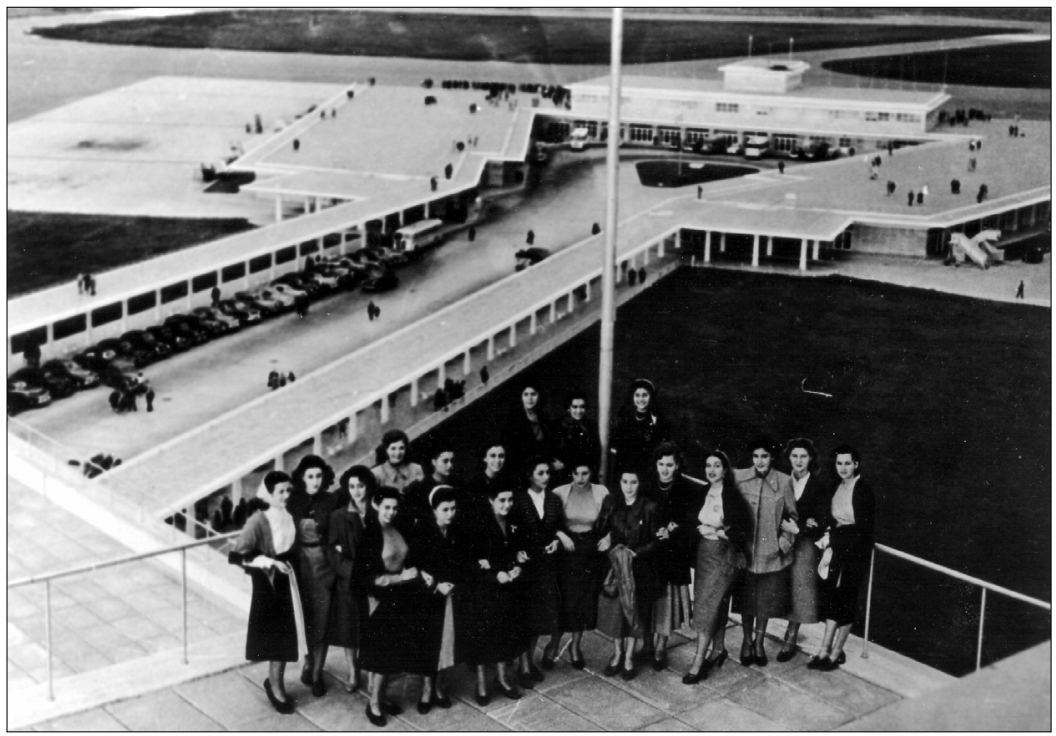

Fig. 27.-Candidatas a Reina Nacional del Trabajo durante una visita al Aeropuerto Internacional de Ezeiza, 1952, AGN. 
caba también dar entrevistas, una visita a la casa presidencial, a los diarios y a los templos donde cotidianamente se materializaba el bienestar: los gremios o los hogares, de las empleadas o de tránsito de la Fundación Eva Perón. Además, frente a la insatisfacción de una vida de privaciones asociada con las condiciones de vida material de la clase obrera, la realeza hacía realidad el sueño del viaje, el conocimiento de otras geografías. Eran fotografiadas cuando llegaban a Buenos Aires (Fig. 25), viajando por la ciudad (Fig. 26), en el aeropuerto de Ezeiza (Fig. 27). En todos los casos las imágenes recortaban caras sonrientes, bellas, naturales, modernas.

A través de las fotografías se fue formando un consenso general sobre la importancia de la belleza natural: para el régimen peronista su exhibición permitía la revalorización y la dignificación del trabajo femenino, que ya no humillaba a la mujer sino que le aseguraba el reconocimiento público; para la población masculina, sea los miembros del jurado sea los espectadores, la belleza natural de las elegidas servía para identificarlos como los poseedores de un bien preciado; mientras que para las mujeres la belleza "accesible" de las reinas, alejada de exquisiteces y del modelo de la "femme fatale", permitía su fácil identificación no sólo con las elegidas sino con un mundo de ensoñación alimentado por la literatura. En otro nivel, esas mujeres eran como Eva Perón, reproducen en cierta manera su experiencia, actualizan la historia de la joven humilde que se convirtió en reina de su pueblo y, como recreación de esa persona, ellas también amaban el hogar, a Perón y a los pobres. Ruth Sesma Romero, la reina de 1949, decía en un reportaje que, suponiendo que su reinado "en lugar de ser simbólico fuera de hecho, haría que todo aquello que sueña la señora María Eva Duarte de Perón cristalice: que sean realidad sus ambiciones, que el éxito corone sus patrióticos esfuerzos y que ese ideal que sustenta de una Patria efectivamente justa fuera un hecho..., decretaría que no hubiera ricos tan ricos ni pobres tan pobres. Dedicaría todos mis esfuerzos a apoyar su obra, tan profundamente cristiana, tan esencialmente solidaria con el dolor y la miseria, y decretaría que todas las mujeres dedicaran un poco de la ternura que atesora su corazón a aliviar la situación de sus hermanos de raza y de sangre, creando una conciencia argentina basada en su ejemplo magistral" . ${ }^{47}$ En 1950, Práxedes Mesconi (Práxedes I) señalaba que su aspiración era "tener un hogar y muchos hijos para engrandecer esta Patria de Perón". ${ }^{48}$ Como Evita, ellas también aspiraban a ser un "puente" entre Perón y su pueblo.

47 Democracia, 3 de mayo de 1949.

48 Democracia, 4 de mayo de 1950. 
Edna Alicia Constantini, reina nacional del trabajo de 1952, dijo: "Mi reinado es un homenaje que la Confederación General del Trabajo rinde a todas las mujeres trabajadoras de la patria. Yo no soy sino el vehículo de ese homenaje y consciente de mi situación lo recibo en nombre de todas mis hermanas peronistas argentinas". ${ }^{49}$

Las fotografías, así como los medios de comunicación masivos - la prensa, la publicidad y el cine- no sólo reforzaban una "cultura de la belleza" como parte importante de una "cultura de masas", sino que servían también a los propósitos políticos del régimen peronista.

El año 1951 estuvo marcado por el lenguaje de la eficiencia en la producción y en el trabajo. Mujeres y varones buscaban batir las marcas haciendo realidad las imágenes asociadas con la producción, la eficiencia, la organización y la modernización, promovidas desde la década del veinte, y, particularmente, cumplir con las metas de producción y la disciplina laboral que promovía el gobierno nacional. Dos fotografías resultan significativas en este registro. El 29 de abril de 1951 las "reinas regionales del trabajo" visitaron un taller de confección y "alentaron" a las jóvenes obreras en el esfuerzo que estaban realizando (Fig. 28). Ese mismo año, el presidente Perón y Evita recibían, en el Salón Blanco de la casa de gobierno, a las trabajadoras de diferentes gremios que habían establecido marcas extraordinarias de producción (Fig. 29). No sólo las jóvenes bellezas ungidas como reinas del trabajo eran recibidas por los líderes indiscutidos del peronismo, también estaban allí las mujeres que, aunque confinadas discursivamente en el hogar, se incorporaban al conflictivo mundo del trabajo. La joven sentada frente a su máquina de coser representa, no obstante, a una mujer tradicional (la costura es para las mujeres), al mismo tiempo que encarna a una mujer moderna: se viste según la moda y combina armónicamente el lazo que sujeta sus cabellos con el diseño de la tela de pollera (Fig. 28). La mujer moderna debe tener una apariencia cuidada y, además, la imagen profundiza la uniformidad del aspecto femenino alrededor de modelos difundidos por la prensa destinada a las mujeres más de una década atrás.

La cultura visual del peronismo es ambivalente: por un lado fija papeles tradicionales de manera rígida y, por otro, los democratiza al producirlos en gran escala y al hacerlos visibles para la multitud. Promueve el confinamiento de la mujer en el "apacible" mundo del hogar y la impulsa a

49 Democracia, 3 de mayo de 1952. 


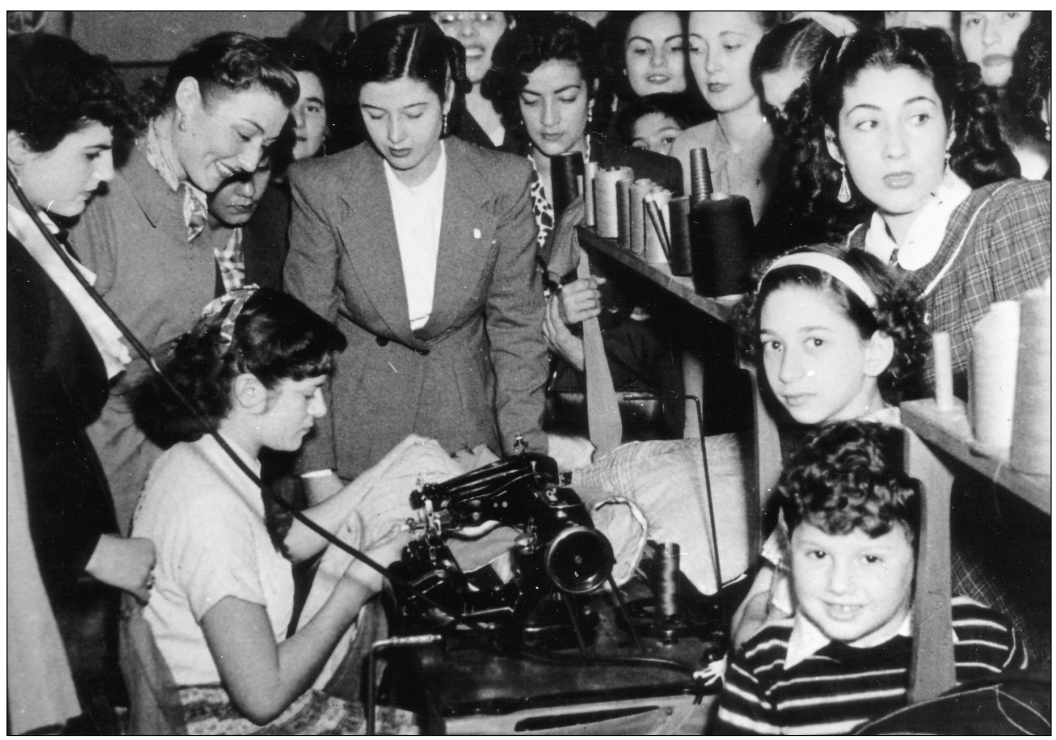

Fig. 28.-Las candidatas a Reina Nacional del Trabajo visitan una planta textil y estimulan a las jóvenes trabajadoras a cumplir con las metas de producción, 1951, AGN.

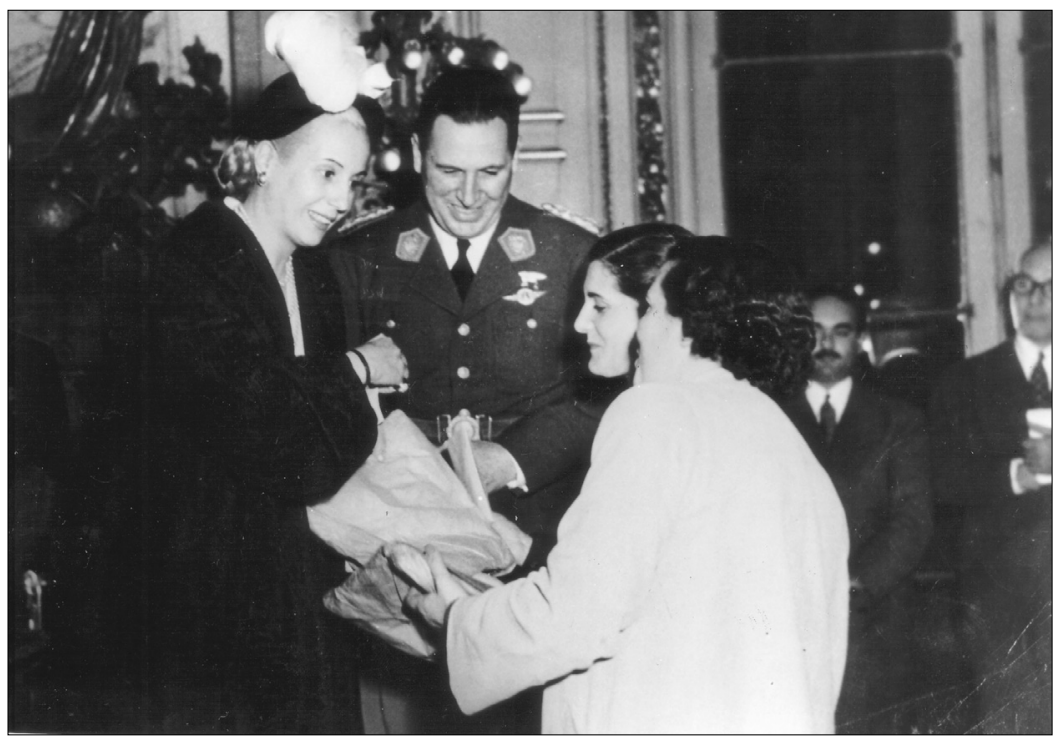

Fig. 29.- Perón y Evita reciben a las jóvenes trabajadoras que cumplieron metas de producción en la Residencia Presidencial, 1951, AGN. 
ocupar los espacios públicos. Se podría afirmar que permanecen en constante tensión procesos de autoafirmación de las mujeres, en particular las pertenecientes a los sectores populares, así como se reformula su subordinación. Las mujeres, incluso la propia Eva Perón, son glorificadas, pero la gloria no alcanza para democratizar el poder.

La imagen más clara de la conformación de este lenguaje ambiguo está representada por dos fotografías. En 1949 la reina nacional tenía su trono sobre dos elementos claros de la iconografía del peronismo y de la Confederación General de los Trabajadores (CGT): el puño cerrado, símbolo del esfuerzo, de la decisión y del trabajo y el engranaje, representación del trabajo industrial (Fig. 30). En la Fig. 31 la reina y su séquito es rodeada por la multitud. La multitud en las calles fue el signo de la época y está presente también en la Fig. 30. El desfile del año 1951 fue también "magnífico" y la reina desfiló en una carroza ornamentada con un gigantesco engranaje. "Bellas y sonrientes" desfilaron por la ciudad la reina y su séquito ("auténticas bellezas criollas"). Ese año también lo hicieron los "esforzados obreros que batieron récords de trabajo y producción". ${ }^{50}$ En una carroza los trabajadores intervinieron en el desfile con sus ropas de trabajo (Fig. 32). En realidad ellos eran los auténticos representantes del trabajo y del poder.

\section{"No queremos carnaval, asamblea popular"}

El golpe militar de 1955 puso fin a las fiestas del trabajo y a la elección de las reinas. El Partido Peronista y sus militantes fueron perseguidos por el nuevo gobierno militar. La fiesta había terminado abruptamente. Pero en 1973, luego de varias décadas de inestabilidad política, de proscripciones, de esperanzas y de frustraciones, el peronismo volvió al gobierno. Sin embargo, el país había cambiado notablemente y se había extendido una cultura de la rebelión que en sus versiones más extremas se expresaba a través de las organizaciones armadas, sean ellas peronistas o marxistas. Además hombres y mujeres jóvenes, más que los trabajadores, habían ganado las calles cuando Perón regresó al país, cuando Héctor J. Cámpora fue elegido presidente bajo la consigna de "Cámpora al gobierno Perón al poder" y cuando Juan Domingo Perón fue electo por una aplastante mayoría para la presidencia de la nación por tercera vez.

50 Ambas fotos fueron publicadas por El Laborista, 3 de mayo de 1951. 


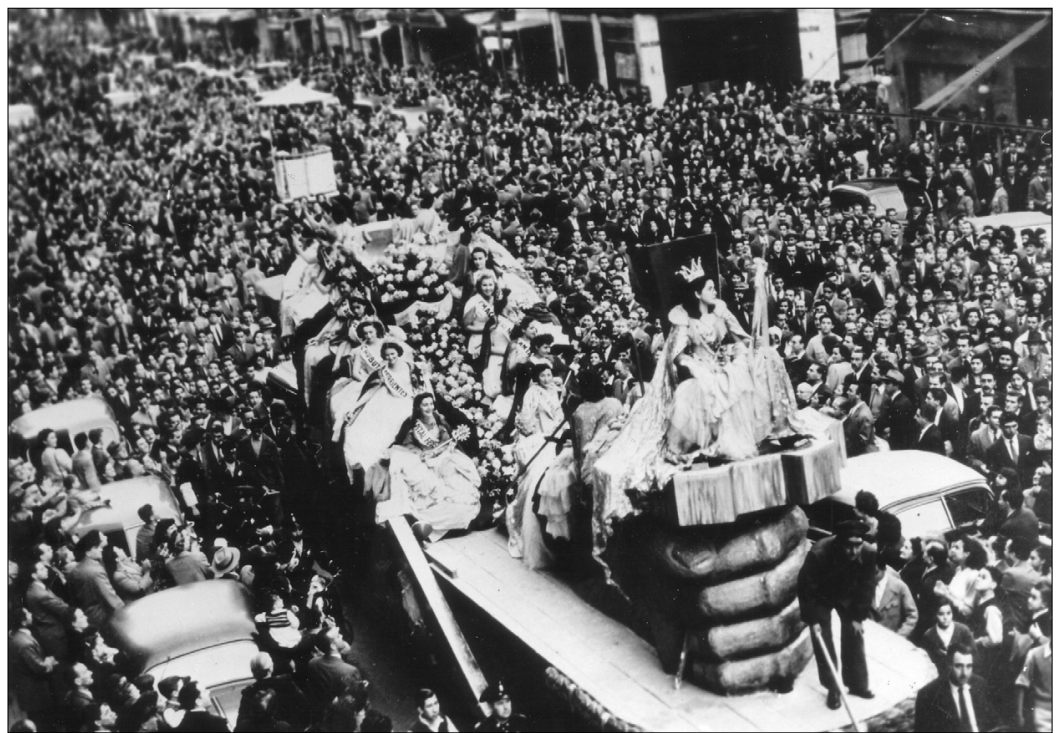

Fig. 30.-Desfile en la Ciudad de Buenos Aires, 1 de mayo de 1949, AGN.

Fig. 31.-La Reina Nacional del Trabajo rodeada por la multitud, 1 de mayo de 1949, AGN.

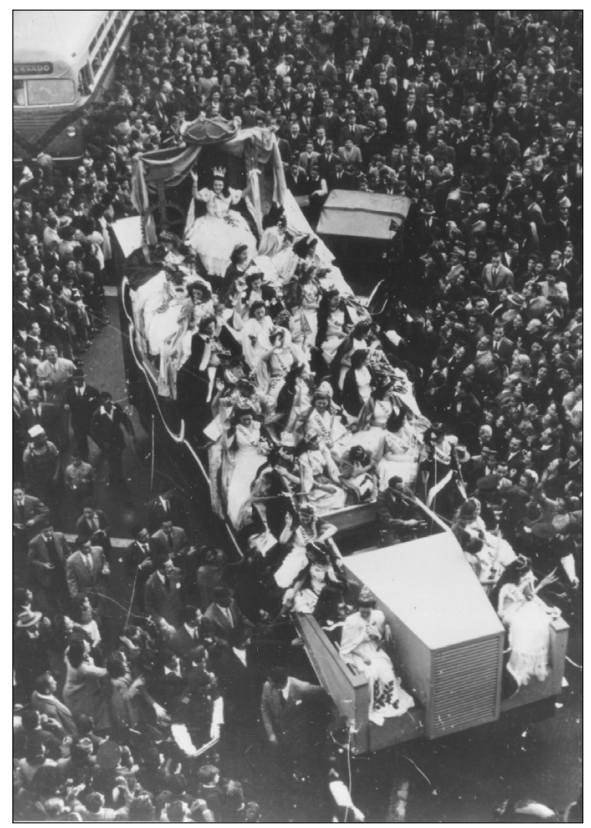




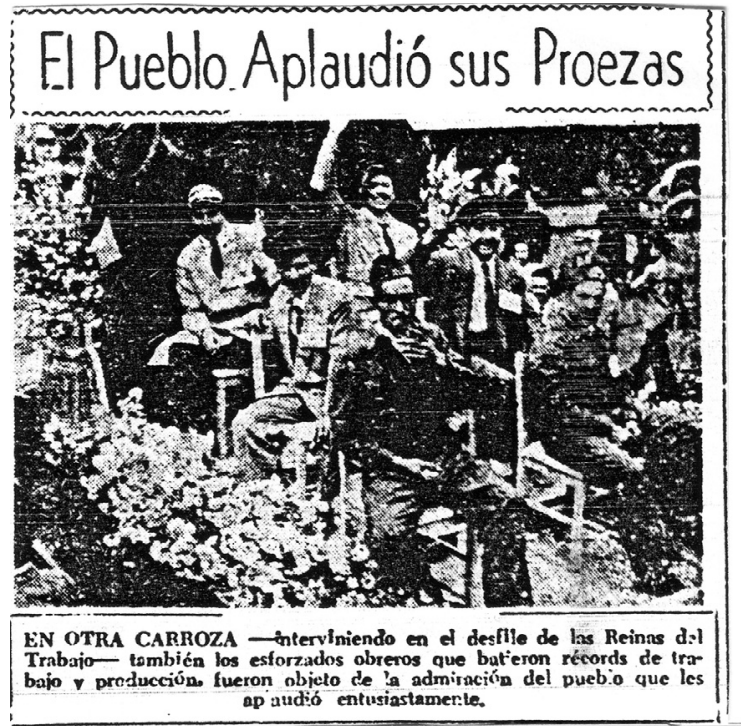

Fig. 32.- Trabajadores que cumplieron metas de producción desfilan el 1 de mayo de 1951. El Laborista, 3 de mayo de 1951.

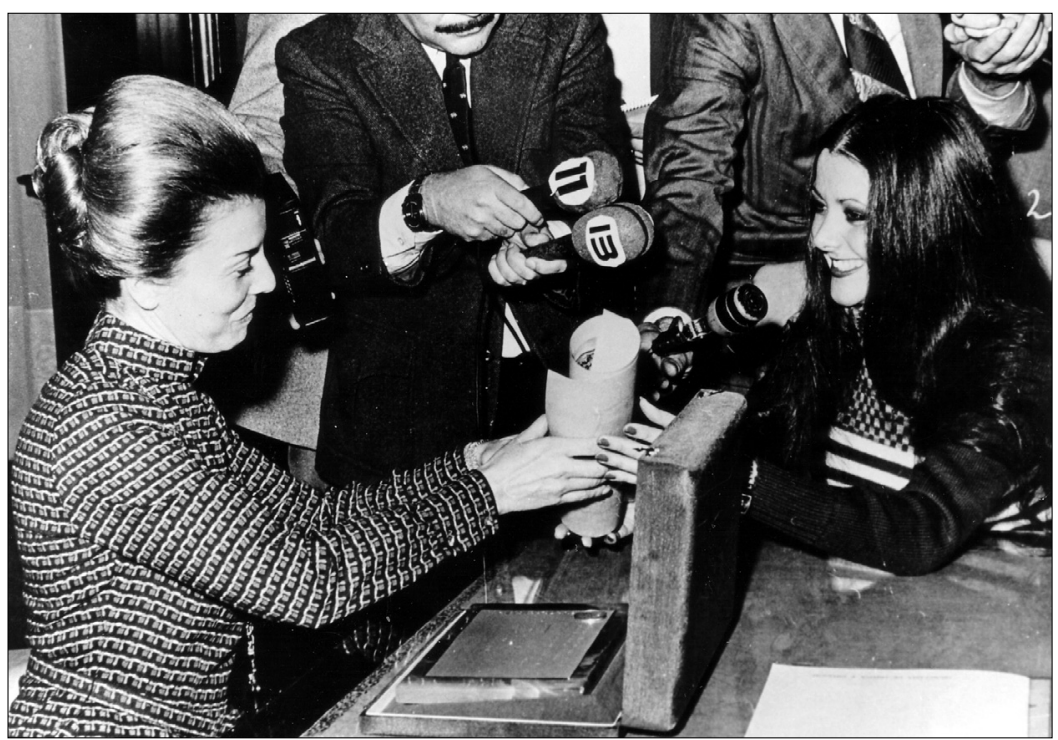

Fig. 33.--Isabel Martínez de Perón entrega el certificado de Reina Nacional del Trabajo de 1975, AGN. 
La tensión entre el intento de Perón de restablecer el propio pasado del peronismo y el del peronismo revolucionario de apoyarse en esas mismas tradiciones para forjar un bloque de izquierda estallaba a cada paso. ${ }^{51}$ El intento de restaurar el pasado se hizo evidente en la celebración del 1 de mayo y en el restablecimiento de la elección de las reinas del trabajo. Claro que el sentido de una cultura y del espectáculo de masas asociado con el trabajo, que había sido un aspecto clave de las fiestas del pasado, no podía restituirse tan fácilmente. En el año 1974 la confrontación en el movimiento peronista había llegado al límite del absurdo cuando decenas de militantes de la Juventud Peronista, comunistas, miembros del Partido Revolucionario de los Trabajadores (PRT), del Partido Socialista de los Trabajadores (PST) y de otras fuerzas de izquierda fueron asesinados por grupos de la derecha peronista.

La preparación de los actos del 1 de mayo fue tensa, pues ambos grupos buscaban prevalecer. La derecha peronista había realizado una clara amenaza unos meses antes: "O los vivos se van al mazo o la cosa termina de la peor manera", escribieron en El Caudillo, órgano de la Juventud Peronista de la República Argentina (JPRA). ${ }^{52}$ La Juventud Peronista (JP) y Montoneros buscaban "romper" el supuesto cerco que rodeaba a Perón y se preparaban para la movilización del 1 de mayo con el apoyo del sindicalismo combativo.

El 1 de mayo de 1974, desde la mañana bien temprano, comenzaron a llegar los militantes de la Juventud Peronista y se acercaron a la Plaza de Mayo, pero tenían dificultades para ingresar a la misma. Esa misma mañana Perón habló en el Congreso Nacional de la necesidad de un proyecto nacional homogéneo en el que todos los sectores de la sociedad, los trabajadores, los empresarios, los intelectuales junto a las Fuerzas Armadas y la Iglesia, contribuyeran para su realización.

A la tarde se celebró el acto en la Plaza de Mayo. Hubo un claro intento de recrear el espectáculo. Antonio Carrizo, el conocido locutor radial, presentó a la actriz y cantante Susana Rinaldi, quien recitó un poema. En el palco estaban otros actores, como Santiago Gómez Cou o José Marrone. En la Plaza de Mayo la tensión crecía con el ingreso de las columnas de JPMontoneros y el despliegue de sus carteles. Las consignas se coreaban dejando claro cuál era el posicionamiento de cada uno de los bandos.

51 Godio, Julio: Perón. Regreso, soledad y muerte (1973-1974), Hyspamérica, Buenos Aires, 1986.

52 El Caudillo, 8 de febrero de 1974. 
Cuando unos coreaban Mon-to-ne-eros o "¿Qué pasa, qué pasa, general, que está lleno de gorilas el gobierno popular?", otros gritaban Ar-gen-ti-na, frente a "Duro, duro, estos son los Montoneros que mataron a Aramburu", se escuchaba A-se-sinos.

Frente al espectáculo que se desarrollaba en el palco, la consigna de "No queremos carnaval, asamblea popular" expresaba la oposición a la escena y, en un costado, varias jóvenes esperaban que se eligiera a la reina del trabajo. Cuando llegó Perón en helicóptero a la Plaza, durante diez minutos los jóvenes gritaron: "El pueblo te lo pide, queremos la cabeza de Villar y Magaride". Faltando diez minutos para las 17 horas la vicepresidenta Isabel Perón coronó como Reina del Trabajo de 1974 a María Cristina Fernández, representante del gremio de Obras Sanitarias, de 21 años. Entre los premios recibidos por la reina de los trabajadores figuraban dos pasajes a Europa, estadía paga y dinero para gastos personales. En la Plaza, alrededor de cincuenta mil personas coreaban: "Evita hay una sola". ${ }^{53}$

La fractura era inevitable y las fotografías de la prensa sólo rescatan la magnitud del conflicto y la figura de Perón. El Archivo General de la Nación no conserva las fotografías de la plaza (tal vez no están catalogadas o se perdieron irremediablemente, como ha sucedido con otros artefactos culturales). La única foto encontrada muestra a Isabel Martínez de Perón entregando a la reina del trabajo de 1975 su pergamino (Fig. 33). En ese año la elección fue distinta, pues se realizó en los estudios de televisión de Canal 7 y fue transmitida por la red de televisión de todo el país.

Teresa Reales, una "bella santafecina" de 23 años, fue coronada como Reina Nacional del Trabajo 1975. La joven representaba a la Unión Argentina de Artistas de Variedades. No sólo el escenario de la elección había cambiado radicalmente, también se modificó la composición del jurado que esta vez estuvo integrado por María Fernanda, especialista en modas, María Amelia Argentina, ex Miss Argentina y Miss Universo, el cantante Alberto Marcó, el modista Vittorio y la cosmetóloga Norma Palkowsky. Según las noticias periodísticas, no sólo se tuvo en cuenta la belleza de las candidatas sino también su nivel cultural y su condición de mujer que trabaja. El nivel cultural no era considerado como importante en las selecciones del primer peronismo, aunque algunas candidatas intentaran exhibir sus conocimientos. Algunas señalaban que les gustaba la lectura y mencionaban aquellos libros que formaban parte de los programas

53 Para una descripción de los acontecimientos puede consultarse La Razón, 2 de mayo de 1974. 
escolares de lengua y literatura; María de Jorge Isaac y Amalia de José Mármol fueron los textos mencionados. En 1975, la soberana, además de las tradicionales clases de piano y danzas, había incorporado a sus conocimientos la expresión corporal y la cultura física, así como el aprendizaje de un idioma extranjero: el francés. Según el cronista, dicha lengua era hablada con fluidez por la joven. También le encantaba leer teatro y entre sus escritores preferidos menciona a Ibsen. Para demostrar ese nivel cultural exigido a las candidatas señaló que le gustaba la "literatura moderna y la música expresionista". ${ }^{54}$

Fue la última vez que se eligió una Reina Nacional del Trabajo, y con su desaparición también se puso fin a una época fuertemente asociada con el proyecto político del primer peronismo. Entre 1955 y 1975 se habían producido muchos cambios en la situación de las mujeres y en las relaciones de género. Las mujeres vivieron sus experiencias laborales, políticas y sociales con una "relativa" mayor independencia; las revistas femeninas difundieron imágenes de mujeres modernas, y aunque la maternidad y la vida hogareña seguía siendo la función y el lugar privilegiado para ellas, desde diferentes lugares y actores comenzaron a cuestionarse las relaciones intergenéricas (los varones podían "ayudar" a sus esposas en el trabajo doméstico sin comprometer su virilidad), se modificaron aspectos significativos de la vida sexual con la difusión de las píldoras anticonceptivas y se transformaron las representaciones de las mujeres con los cambios provocados por las modernas pautas publicitarias que, por otra parte, promocionaron nuevos productos y valores transformando las pautas de consumo.

\section{Belleza femenina y política: un epílogo posible}

En 1949 un panfleto de la agrupación gremial peronista de los ferroviarios impulsaba a la reflexión de los trabajadores sobre el 1 de mayo. Es interesante el contenido que difundía esa herramienta fundamental para la acción política de los trabajadores. Decía en uno de sus párrafos: "Reflexionad, camaradas, mientras en nuestra Patria se festeja el día de los trabajadores, encabezando las manifestaciones el Presidente de la República, General Perón y su digna esposa Doña María Eva Duarte de

54 La Razón, 2 de mayo de 1975. 
Perón, alma mártir del sacrificio para el bienestar de su pueblo de descamisados acompañando a todos los trabajadores confundidos en una sociedad justa y libre, se canta el himno patrio, se entona la canción del trabajo, se eligen las reinas del trabajo, se le abona el sueldo a los obreros, cosa que antes del 1943 esto era un primero de Mayo de protesta y sangriento como sucede en el resto del mundo, y en el paraíso terrenal del comunismo se realiza un 1 de Mayo haciendo ostentación de un poderío militar, desfilando un inmenso ejército de armamentos modernos para masacrar a los pueblos. Compañeros, que diferencia grande, nuestro Líder al frente de su pueblo obrero, da el grito de paz, de confraternidad entre los pueblos adoptando la tercera posición al grito de basta de guerra y declarando la justicia social y un mayor bienestar a los trabajadores del mundo". 55

Según la agrupación obrera, la elección de las reinas del trabajo formaba parte del cambio que se había producido en Argentina con la llegada de Perón al gobierno. Representaba los logros del nuevo gobierno y la instauración de una era de felicidad para los trabajadores.

Sin embargo, no era el único sentido atribuible a la repetición del ritual festivo y a la glorificación de la belleza de las mujeres. Las "reinas" formaban parte del "inconsciente óptico del peronismo". Eran parte del espectáculo visual que orientaba los festejos y que daba forma a una experiencia político cultural, donde las mujeres ocuparon un lugar preponderante pero subordinado.

En esa formación político cultural, la definición visual de la feminidad que hemos seguido a través de las fotografías implicaba la noción de belleza, de gracia y de armonía, entendida como resultado de un don natural. La belleza de la mujer era exhibida públicamente para honrar al trabajo y se hacía en abierta confrontación con las imágenes del pasado, donde el trabajo femenino no sólo humillaba a las mujeres sino, lo que es peor, también las deformaba y transformaba en objetos imposibilitados de producir placer visual.

La elección de las reinas puede ser interpretada como una forma de glorificación de las mujeres, pero la formación político cultural del peronismo está impregnada de ambigüedades, y el dominio pictórico realizado a través de las fotografías de un sujeto femenino pasivo, humilde y por momentos trivial era una forma también de hacer valer el poder masculino.

55 Reflexiones sobre el $1 .^{\circ}$ de Mayo. A los ferroviarios y trabajadores peronistas. Panfleto de la agrupación gremial peronista de ferroviarios, Remedios de Escalada, Mayo de 1949. 
El espectáculo ornado con las bellezas femeninas puede ser explicado como expresión de la cultura de masas que, como señala Andreas Huyssen, identifica a esta cultura con la mujer, en contraposición a "una cultura auténtica y real", que sigue siendo prerrogativa de los hombres. ${ }^{56}$ Se corre el riego también de analizar los rituales del 1 de mayo durante el peronismo como una expresión cultural impuesta desde arriba. El análisis de las imágenes fotográficas puede conducirnos en esa dirección, pero, como dice Huyssen citando a Stuart Hall, el sujeto oculto en el debate de la cultura de masas son las masas, sus luchas, sus aspiraciones políticas y culturales y también su apaciguamiento a través de las instituciones culturales. ${ }^{57}$ Las mujeres formaban parte de esas masas, "golpeaban la puerta de una cultura dominada por los hombres", sólo que todavía sus voces son borrosas. Las fotografías dan cuenta parcialmente de las tensiones que la glorificación de la belleza femenina en el escenario de un ritual político podía tener para las mujeres. Las palabras que hemos tomado de la prensa ("tentación", "imposibilidad", "límites") son un indicio de las contradicciones posibles entre las maneras en que ellas se veían a sí mismas y como las veían los demás.

El fin del primer peronismo con el golpe militar de 1955 implicó el fin de los reinados, pero no el de las transformaciones asociadas a la imagen femenina, a los cambios en las relaciones de género y a las modificaciones entre lo público y lo privado. La escasez de imágenes conservadas en el Archivo General de la Nación sobre la elección de las reinas del trabajo en 1974 y 1975 llama la atención y se pueden realizar algunas inferencias. En un nivel, se puede pensar la imposibilidad del peronismo de reactualizar el sentido del espectáculo y de la glorificación de la belleza femenina del período 1948-1955, a partir del malentendido existente en el seno del propio peronismo entre los sectores juveniles y las direcciones sindicales y Perón. Las nuevas fuerzas políticas de izquierda que se habían desarrollado, tanto dentro como fuera del peronismo, marcaron los límites de ese esfuerzo por recuperar los sentidos del pasado. No fue sólo eso, esa nueva izquierda se desenvolvía en los marcos de sus propios límites y contradicciones. Paralelamente se abrían para las mujeres nuevos desafíos y posibilidades.

56 Huyssen, Andreas: Después de la gran división. Modernismo, cultura de masas, postmodernismo, Adriana Hidalgo editora, Buenos Aires, 2002, pág. 94.

57 Huyssen: Después de la gran división..., págs. 94-95. 